\title{
CHAPTER IX. \\ DESCRIPTION OF THE COAL BEDS OF CENTRAL IOWA.
}

The coal deposits of the counties embraced within this area are by far the most important in the state. The production of coal in this region is much greater than in any of the others. The limits of the district are of course perfectly arbitrary and are merely selected for convenience in the treatment of the subject. Forming the median portion of the region traversed by the Des Moines river it is surrounded on all sides by counties whose surfaces are occupied largely by Coal Measure strata. 'The maximum thickness of the coal bearing beds of the area is probably between four hundred and five hundred feet. Although the Coal Measures become attenuated to the eastward the Lower Carboniferous limestones are nowhere exposed at the surface except in the sontheastern corner of the district where in Marion and Mahaska counties the Saint Louis limestone outcrops in some of the beds of the principal streams. Thus over much of the central region considerable depths may be penetrated before reaching the Coal Measure basement. Towards the east the heary drift deposits prevent the exact boundaries of the coal field from being determined with accuracy over a part of the region. The numerous well borings, however, have enabled the leading features to be made out and the actual 
limits eastward are probably not far from those assigned them on the accompanying map. Toward the west the Upper Coal Neasures come in, covering the more productive deposits, which come to lie deeper and deeper in that direction. Outliers of Cretaceous also occur in some of the more western counties but in no case are these very extensive.

The counties embraced in the central district are: Guthrie, Dallas, Polk, Jasper, Poweshiek, Madison, Warren, Marion and Mahaska.

\section{GUTHRIE COUNTY.}

This county lies in that part of the coal field where the Coal Measure strata begin to pass beneath rocks much younger. The entire surface of the county being mantled by drift to a considerable depth the natural outcrops of the underlying stratified rocks are seldom found well exposed.

The eastern margin of the Iowa Cretaceous stretches out into the western and central portions of the county, ocenpying fully one-third of the entire district. As this formation here presents only its attenuated edge it is not very well marked. In the extreme western portion of the county Cretaceous rocks are exposed along the various streams showing a thickness sometimes of eighty or ninety feet. The beds consist chiefly of ferruginous grits and conglomerates with a development of argillaceous shales. In a few places brown coal has been found in thin seams two or three inches in thickness. While probably not of any economic value at present these lignites are of interest in showing the presence in the county of Cretaceous as well as Carboniferous coals. Indeed these two coals have been noticed in the same section, within 
thirty feet of one another, a few miles west of Guthrie Center.

Besides the rather extensive development, in the western and northwestern parts of the county, of the Cretaceous which seems to resemble portions of the main body there are doubtless outliers of greater or less extent. That these deposits were much more extensive at one time than at present is shown by the occurrence in the drift of large fragments and boulders of Cretaceous sandstone charged with fossils. These blocks have been found scattered eastward through Dallas and Polk coumties. Some of the fragments contain fossils in a good state of preservation, among which have been recognized specifically a number of species of sharks and gasteropods of undoubted Cretaceous types. The good preservation of fragile mollusks and the comparative softness of the masses indicate clearly that the fragments are not far removed from the locality of original deposition. Outliers which are found capping the hills along the rivers may therefore be regarded as portions of the main mass, the larger streams having cut their channels completely through into the Coal Measures below.

With the exception of the comparatively thin covering of Cretaceous beds and the mantle of drift the county may be regarded as entirely made up of Coal Measure strata. Like in most other counties situated in this part of the state the coal beds have been sought for principally only in the hillsides along the streanis. Like also in the neighboring counties prospecting to a depth of three to four hundred feet would doubtless disclose much more extensive seams than are now known anywhere within the limits of the district, for coal in workable beds probably exists over much of the county. At the present time, 
however, it has been developed almost entirely along the streams, most of the product being taken out of small local drifts. The coal obtained in this manner is all taken from thin seams and is in some instances poor in quality. At present there are a score or more of mines operated in the region but with one or two exceptions they are country banks furnishing supplies for local trade only. A number of shafts have been put down but they rarely reach a depth greater than seventy-five or eighty feet. No systematic search has yet been made for a deeper coal horizon.

The principal places where coal is mined are situated along the Middle Raccoon river where the majority of the natural exposures are located. Linden, just over the line in Dallas county, Panora, Fansler and Bayard are the leading points. Coal is also mined to a considerable extent on the South Raccoon, and in the northeastern part of Guthrie. North of Stuart mines have also been opened in the extreme southeastern part of the district.

Jamaica District.-This is in the extreme northeastern corner of Guthrie, near where coal has been mined in Dallas county in the valley of the Raccoon river not far from the boundary line. It forms a part of the region which in Dallas has been called the valley of the North Raccoon river. 'This stream does not enter Guthrie; but on a small creek known as the Greenbrier which flows across the northeastern corner of Guthrie into the Raccoon near Dawson and about a mile northeast of Jamaica (Tp. 81 N., R. XXX W., Sec. 1, NE. qr., SW. $\frac{1}{4}$ ) there is located the Simons or Greenbrier mine. It is a shaft thirty feet in depth, with coal two feet in thickness. The vein thickens toward the east and becomes better in quality. It rests upon a bed of fire clay several feet in 
thickness and is covered by a hard black shale, as shown in the following section :

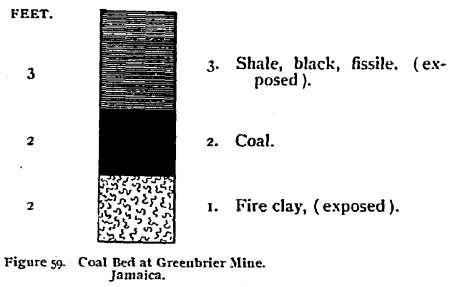

The mine is worked chiefly during the winter; and an important local trade is supplied. A short distance east of here at Dawson, in Dallas county, considerable mining is carried on. At least six seams of coal are known to occur, though with two exceptions they are too thin for profitable working. On the Raccoon near here important mining operations have been carried on; while six or seven miles east, at Angus, deeper veins are known to exist and one of these has been quite extensively mined. It seems quite probable that this coal horizon extends westward under a portion, at least, of Guthrie county.

Middle Raccoon Valley.-The largest coal mines in Guthrie are situated along the Middle Raccoon river. The exposures showing coal above the river level are quite numerous from the southeast corner where the stream leaves the county to the northwest corner where it enters. Several veins of coal outcrop in the bluff's and are reached at a number of places by drifts and shallow shafts. At the sontheast corner the coal basin is a continuation of the Redfield district of Dallas comnty. Half a mile east of 
the Guthrie county line at Linden is the Dale mine where considerable coal has been mined. Two miles southwest of this place, on the south side of the river, is the Stapes coal mine (Tp. 79 N., R. XXX W., Sec. 36, NE. qr., NE. $\left.\frac{1}{4}\right)$. The vein worked is seventeen inches in thickness. As at the opening half a mile to the eastward, known as the Keeler mine, there are numerous clay seams running through the coal and the clay partings so characteristic of this vein also occur here. The coal bed is comparatively free from faults or "troubles." In the neighborhood of the mine mentioned there are also a number of small drifts operated from time to time, but as yet they have not been systematically worked. Just beyond the mine mentioned coal and bituminous shale are frequently seen outcropping in the hillsides on the south side of the river. On the opposite side of the Raccoon, directly across from the Stapes mine, are also several good exposures, one of which may be described as :

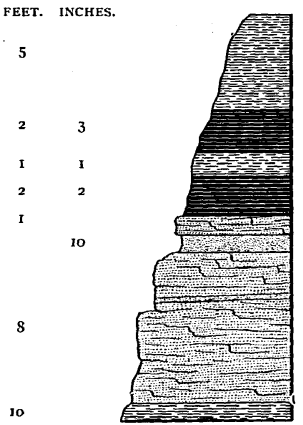

8. Shale, light colored.

7. Shale, bituminous.

6. Shale, light colored.

5. Shale, bituminous.

4. Sandstone, hard, yellow, ferruginous.

3. Sandstone, friable.

2. Sandstone, hard, massive, with thin shale partings.

I. Shale, light colored, arenaceous.

Figure 60. BIuff on Middie Raccoon. Near East County I,ine of Guthrie. 
About two miles to the northwestward is the Tam mine (Tp. 79 N., R. XXX W., Sec. 22, SE. ql., NE. $\frac{1}{i}$ ). It was a small drift and is said to have worked a seam of cannel coal twenty-two inches in thickness. A mile to the northwest and about three miles directly south of Panora on the south side of the river several openings have been made a short distance from the stream. The principal mine is the Burgess. It has only been recently opened and is a shaft fifty-four feet in lepth, working twenty inches of coal. A second vein a short distance below has been located but has not been opened up yet. A quarter of a mile to the northward are the Fisher and Dygart mines, the former working the same vein as the Burgess mine. The Fisher shaft is thirty-six feet in depth. Near the Dygart the section shown is :

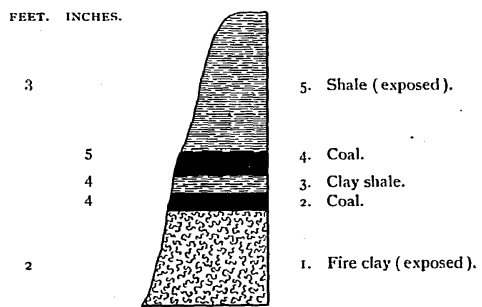

Figure 6r. Dluff at Dygast Drin. Panora.

Near the river, on the east side, a mile and a half below Panora, a number of openings have been made, though none of them are in active operation. In this vicinity the coal is exposed in the bluffs, the principal vein here, which is one foot thick, being known as the Panora coal. The section is : 


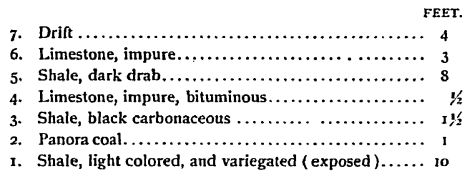

Directly opposite Panora on the river bank St. John gives the following section at Wasson's coal mine, near the old Panora woolen factory:
II. Shale, blue and reddish.
10. Limestone, rather impure, in three layers with shaly partings, lower one fragmentary and fossil- iferous
9. Shale, dark blue
8. Limestone, impure, compact, bluish, containing fossils $\ldots \ldots \ldots \ldots \ldots \ldots \ldots \ldots \ldots \ldots \ldots \ldots \ldots, 2 / 3$
7. Shale, dark, bituminous.................... $11 / 2$

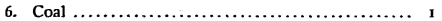
5. Shale, light colored $\ldots \ldots \ldots \ldots \ldots \ldots \ldots \ldots \ldots$ ro
4. Shale, variegated $\ldots \ldots \ldots \ldots \ldots \ldots \ldots \ldots \ldots \ldots, 6$
3. Shale, bluish............................. 3

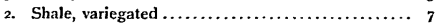
1. Sandstone, micaceous (exposed) .............. I2

FEET.

A short distance to the westward of the last mentioned point is the Reese mine, (Tp. 79 N., R. XXX W., Sec. 6, NE. q1., SE. $\frac{1}{1}$ ). It is a shaft ninety feet deep working coal eighteen inches in thickness. No "horsebacks" or faults are encountered and the seam is quite regular. Clay seams are sometimes met with. The beds associated with the coal vein are:

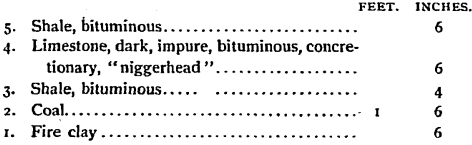




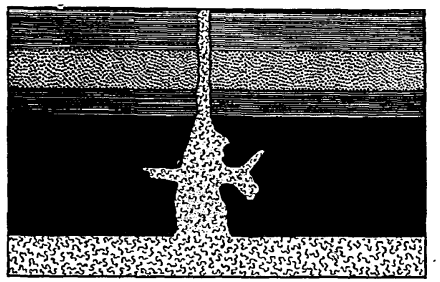

Figure 62. "Clay Seam" in Reese sine. Panora.

The portion of the coal bed represented shows one of the clay fissures commonly met with.

Three miles northwest of Panora is the Harris mine (Tp. 80 N., R. XXXI W., Sec. 25, SW. qr., NE. $\frac{1}{4}$ ), situated about half a mile from the river. It has but recently been opened and is a shaft twenty feet deep, with coal eighteen to twenty inches in thickness. A mile directly north of the mine on south bank of the river a short distance above the wagon bridge there is a good exposure more than 200 feet long showing chiefly sandstones and shales.

In the neighborhood of Fanslers considerable mining has been carried on during the past few years. A mile below the mill is the old shaft of the Jones mine, forty feet deep. The coal is eighteen inches in thickness. At the present time the mine is not in operation. Directly north of the mill site numerous openings have been made, among which is the Scott mine (Tp. $80 \mathrm{~N}$., R. XXXI W., Sec. 9, SE. qr., NW. $\frac{1}{4}$ ). It is a new shaft, seventy-six feet deep, with coal thirty-two inches in thickness. Half a mile northwest on the river bank is the Renslow mine, 
eighty-seven feet in depth. On the opposite side of the river are several mines which were opened a few years ago. These were the Marshman, the Decker and the Oleson. They were all shafts working the same vein of coal at a depth of from sixty to ninety feet. East of the mill a short distance is the Hughes mine a shaft seventy feet deep. The seam is quite regular and from twenty to twenty-two inches in thickness. The coal is worked on the long wall plan and a considerable local demand is supplied. Above the mill a short distance, near the river bank, is another mine, the Marchant, which is a shaft 126 feet deep, with coal two feet in thickness. It has been operated for a dozen years or more and is supplying an important local trade. Further up the stream are the Eclipse and Scott mines and on the opposite side the Thomas shaft. The latter is 142 feet deep with coal twenty-six to twenty-eight inches in thickness. At the Scott two seams of coal are present:

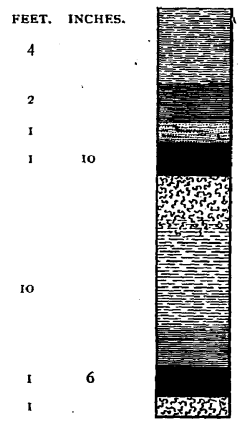

7. Shale, light colored, argillaceous, sandy in places ( exposed).

6. Clay shale, dark, fissile.

5. Sandstone, "caprock."

4. Coal, containing heart shaped pericarps in pyrite, four inches of shaly material at the bottom.

3. Fire clay and clay shales.

Figure 6y. Section of Scott Shaf. Fanslers. 
The bed at the Eclipse shows:

$\begin{array}{cc}\text { FEET. INCHE } \\ 2 & \\ 1 & 6 \\ & 6 \\ 1 & 10 \\ 1 & \end{array}$

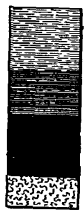

4. Shale, light colored.

3. Clay shale, hard, bituminous, fissile.

2. Coal.

1. Fire clay.

Figure 64. Bed at Eclipse Mine. Fanslers.

About five miles west of Fanslers a number of openings were formerly worked on both sides of the river. The principal mine now in operation is the Eureka ( $\mathrm{T} p$. 81 N., R. XXXII W., Sec. 33, NE. (1r., NTV. $\frac{1}{4}$ ) which is. on the south side of the river and opened in the same vein as the old Mount mine. It has been operated for about twenty years, new drifts being made each winter. The relation of the coal seam and its associated beds are : FEET. INCHES.

$\mathbf{1}$

I

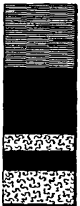

5. Shale, dark, fissile, fossiliferous.

4. Coal.

3. Fire clay.

2. Coal.

I. Fire clay.

Figure 65. Coal seam at Eureka Mine. Mayard.

There are a number of country banks in the neighborhood all working the same conl which is from twelve to eighteen inches in thickness. I distinguishing feature of this seam is a three-inch parting of clay, separating the upper twelve inches of the bed from rest of the seam.

A few miles to the northwestward and about five miles southwest of Bayard another groip of mines is located along the river bank. The principal one of these is the 
Hughes ('Tp. 81 N., R. XXXIII W., Sec. 24, SE. qr., NE. $\left.\frac{1}{1}\right)$. This is a shaft thirty-nine feet deep. A rather important local trade is supplied. For several miles along the river drifts are found some of which have produced considerable coal. The seam exposed varies from one to one and a half feet in thickness. In this part of the county the Cretaceous rocks are found overlying the Coal Measures.

Stuart District.-In the southeastern corner of the county, in Penn township, coal has been mined at a number of places the principal locality being on Deer creek, a small tributary of the South Raccoon. Most of the mines are drifts which have been worked in a very unsystematic way, but yet have taken out considerable coal. Two miles north of Stuart is the Lamb mine (Tp. 78 N., R. XXX W., Sec. 20, SW. qr., NW. $\left.\frac{1}{4}\right)$. It is a shaft thirty-five feet deep, with coal two feet in thickness. On the opposite side of the creek the following section is shown :

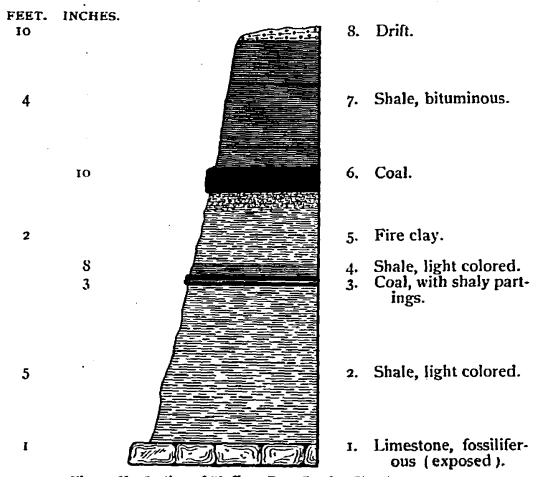

Figure 66. Section of Bluff on Deer Creek. Stuart. ous (exposed). 
A short distance farther north is the Suggert and Saint mine. It has been opened only recently. The shaft is forty feet deep; the coal twenty-two inches thick.

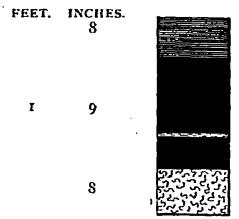

3. Shale, black, fissile.

2. Coal, divided by a $1 \frac{1}{2}$ inch clay parting, in to two benches fourteen and six inches thick.

Figure 6\%. Coal with Clay Parting, in Suggart stine. Stuart.

Coal has also been mined to some extent near Glendon and Menlo but the workings have been abandoned for several years.

\section{DALLAS COUNTY.}

Dallas is underlain everywhere by Upper Carboniferous strata. The workable coal exposed in the natural outcrops along the water courses, probably makes up only a comparatively small portion of the total amount existing in the county. The entire northeastern third of the district is occupied immediately beneath the drift by Lower Coal Measure beds. The rest of the county has the Upper Measures overlying the lower division, which becomes more and more deeply buried towards the southwestern corner. Over this portion of the region the stratified formations near the surface exhibit limestones and calcareous shales in great prominence as compared with the strata of the Lower Coal Measures and they have relatively few coal bearing horizons. Borings in the county from 250 to 400 feet would doubtless reveal a number of coal veins sufficiently thick for profitable working. Heretofore with one or two exceptions the 
coal of Dallas has been mined by means of drifts or slopes in the hillsides, along the streams above the water level. Most of the veins are between one and $\mathrm{a}$. half and three feet in thickness. The popular impression therefore has been that this county does not possess any greater coal supplies than is visible in the various natural outcrops and its annual production would seem to indicate the same thing. A more careful examination of the strata indicates beyond question that the amount of mineral fuel in the county is very much greater than has commonly been supposed, but that it lies somewhat deeper than in the country immediately to the eastward. Therefore, if instead of confining coal prospecting to the surface reins, attention be directed to deeper boring, Dallas would soon greatly increase its ammul production over that now credited to it.

The Lower Coal Measures are well exposed in the northeastern corner of the county. Along the Raccoon river which flows entirely across the county from the northwest to southeast corner numerous outcrops of coal are found. There are also many exposures along the South Raccoon, which with the lower portion of the main stream just mentioned traverses the southern tier of townships from west to east.

Des Moines River Talley-Along this stream the bluffs are usually quite high, often quite precipitous, on both sides of the water course. Numerous good sections of the strata are presented in the deep, narrow ravines opening into the river valley. There are now known to be at least two seams of coal above the water level in this part of the county; and probably more important seams exist below the river bed. The coal has been mined at short intervals along the bluffs on both sides of the 
stream, the openings being country banks which are operated for local use during the colder months of the year. On the east side of the river there are a number of old drifts a short distance above High Bridge. On the west side of the stream near the point just mentioned the Pritchard mine was worked for a long term of years but has recently been given up. The seam of coal is rather thin and is broken through by many clay seams. Although not easily worked there was a good local demand for the output and during the period of its activity a considerable amount of coal was taken out. A section of the bluff shows :

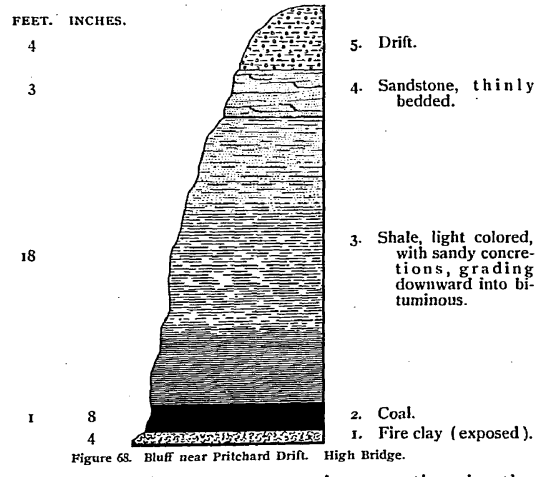

The principal mines at present in operation in the northeastern corner of Dallas are the Tabor shafts. They are situated sontheast of Woodward near the wagon bridge crossing the river (Tp. 81 N., R. XXVIW., Sec. 14, SW. qr., NE. $\frac{1}{4}$ ). They are at present owned by Strange 
and Son. There are three openings all in the same seam of coal and only a short distance apart. They are all shafts, No. 1, the most easterly, being thirty-two feet deep, No. 2 forty-two feet deep and No. 3 seventy-four feet deep. The coal is two feet in thickness and is worked on the long wall method. There is a good roof. No partings are observed in the coal, but occasionally clay seams cut across the vein in certain places. There are a number of openings in this part of the county which are not now operated. Among the leading ones is the Snider slope located a mile west of High Bridge on the west side of the Des Moines river. The coal is two feet thick with a hard shale roof. In mining clay seams were encountered which cut the coal veins in varions directions. Half a mile west of the Snider was the Miller shaft thirty feet deep. Still farther to the northward was the Chestnut Ford mine formerly operated by J. R. Strange. It was a shaft thirty-two feet deep with coal two and a half feet in thickness. In the same vein also is the West shaft which is forty-three feet deep and working in the same vein as the Tabor mine. Coal has been reported in workable seams at a number of points along Beaver creek, which runs nearly parallel to the Des Moines river five or six miles to the westward.

Raccoon Valley.-At Commerce, just over the line, in Polk county, small drifts have been operated in the hills just east of the town. In one place a shaft has been. sunk to the depth of $\mathbf{1 0 0}$ feet where a three foot vein of coal has been worked for a number of years. Between this point and Van Meter no openings are now worked though abandoned drifts and prospecting pits are noticed in various localities. About a mile east of the latter place several thin seams of coal are exposed in the river 
bluft's at various heights above the water level; but none of them appear to have a thickness of more than six or eight inches at this point. The upper part of the section is shown below :

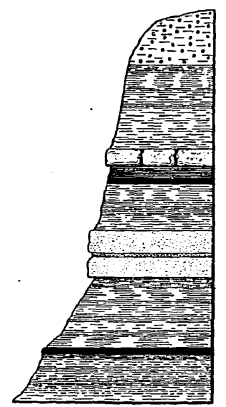

9. 1)rift.............. 10

FEET. INCHES.

s. Shale, light colored $\ldots \ldots \ldots \ldots$,

7. Limestone, compact, fossiliferous.................. 6

6. Shale, bituminous, fissile, coaly below ...................

5. Clay shale, light colored...... 4 6

4. Sandstone. brown, in two heavy beds separated by clay parting, both containing much carbonaceous matter...... 4

3. Shale, sandy above, argillaceous below............. 6

2. Coal....................

x. Shales, and clays variegated (exposed) ............... 5

Figure 6y. Bluff near Raccoon River.

One Milic East of Van Meter.

In the bluffs around Van Meter small drifts have been started at a number of places, but apparently very little coal in commercial quantities has been taken ont. The Chicago and Van Meter Coal Company have a shaft in the western part of town. Two veins of coal are worked. They are about twenty feet apart and each averages three feet in thickness. The upper vein is 285 feet from the surface or about 350 feet below the massive limestone in the top of Van Meter bluff. The coal seams are quite even and regular. The coal is worked partly on the long wall plan, partly on the room and pillar method. The layers and their relations to the coal beds are represented in the following section : 


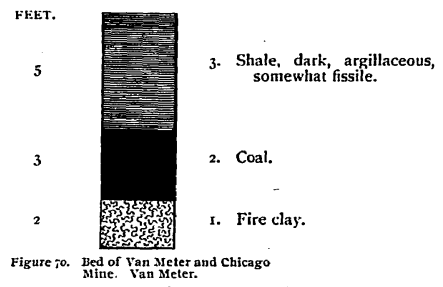

The company have also an extensive brick plant which is operated in comnection with the mining of the coal. Paving, ornamental and fire bricks are manufactured. The clay used in making the brick is obtained partly from the shaft where it is mined in connection with the coal and partly from layers some distance above the coal seam.

Above Van Meter on the main or north branch of the Raccoon the outcrops of coal bearing strata are not well exposed until the vicinity of Adel is reached. Here several thin seams of coal and highly carbonaceous shales are seen in the bluffs along the river. North of town one-half or three-quarters of a mile several openings have been made in the banks of small branches flowing into the river. Four miles above Adel (Tp. 79 N., R. XXVIII W., Sec. 12) two seams of coal have been recognized. They are about thirty feet apart. The upper one is only from twelve to sixteen inches in thickness; while the lower varies from two to three feet. In this vicinity coal has been worked for many years. Among the earlier openings may be mentioned the Chaney mine and Pittman bank. Along a small creek passing through the Chaney farm coal and bituminous shales crop out in the banks for a considerable distance. The Chaney is a drift working 
coal eighteen inches in thickness. The output is local. Several openings were made but none are at the present time in operation. In the bluft of a ravine there are exposed :

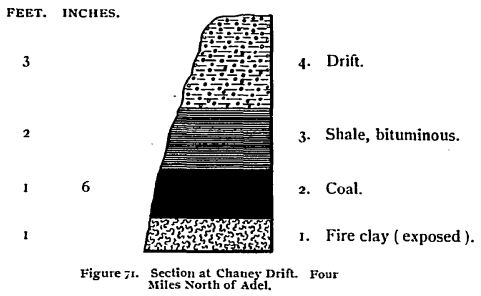

The coal does not appear to thin out in any direction, and is of very good quality. Between this point and Perry, near the north county line, but few good exposures are found along the river.

Just west of the town last mentioned a vein of coal one foot in thickness is exposed on the river a few feet above the water level. Three miles northwest of the station several shafts have been put down. They reach the same vein that is worked in the Angus district, a few miles over the line in Boone county. One of the principal mines, called the Belle, was abandoned only a short time ago.

Five miles west of Perry, at Dawson, several mines have been in operation for a number of years past, the leading one being the Dawson shaft, which is located in the eastern part of the village (Tp. 81 N., R. XXIX W., Sec. 10, NW. qr., SE. $\frac{1}{4}$ ). On the Raccoon bluft an outcrop gives : 


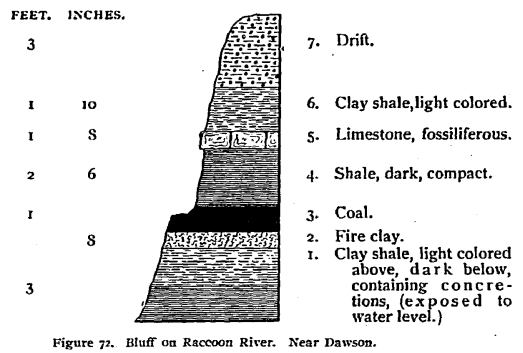

There are two shafts one about seventy-five feet deep and the other 160 feet in depth in the sidehill on the top of the bluffs. The Carboniferous strata at this place are covered with drift to the depth of eighty or ninety feet. No less than six different coal seams are exposed at different levels in the two shafts. At mine No. 1, nearest the river, there are three seams; one, one and a half, and four feet in thickness. Part of the coal in the lower seam is taken out through shaft No. 2, some distance away. The two shafts are comnected by a drop shaft extending from the vein worked in No. 1 to the bottom of No. 2 . The coal is lowered by means of two cages governed by drum and brakes, the loaded cars bringing the empty ones up. In this drop shaft three veins of coal are exhibited below the third or lower vein in shaft No. 1. The lower three are also shown in shaft No. 2. They are one and one-half, two, and three and one-half feet in thickness. Near the bottom of shaft No. 2 a drill hole was put down to a depth of eighty feet without encountering additional coal veins. 
A short distance north of Dawson, near the river, is the Tudor mine which is operated by means of a shaft sixty feet deep. The rein worked varies considerably from one and one-half to three and one-half feet and thins out towards the west. The section shown is :

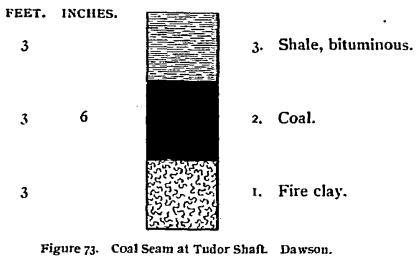

A short distance down the stream the same vein crops out in a river bank. Farther down, a distance of perhaps 150 yards, is an old drift called the Sarginson mine which at present is not being worked.

South Raccoon Valley.-Between Van Meter and De Soto bituminous shales and thin coaly layers are exposed at a number of points in the bluft's along the railroad. For a large part of the distance between the two places the south side of the stream is bordered by steep-sided hills which often form almost mural escarpments, especially where the hard limestone layers are allowed to project out over the softer underlying shales. Between the two points mentioned and for several miles beyond in each direction, the strata are almost on a perfect level, the inclination in eight miles being only a few feet. Several drifts have been opened, but at present there are none in operation. Opposite De Soto station, on Bulger creek, the following section is shown : 


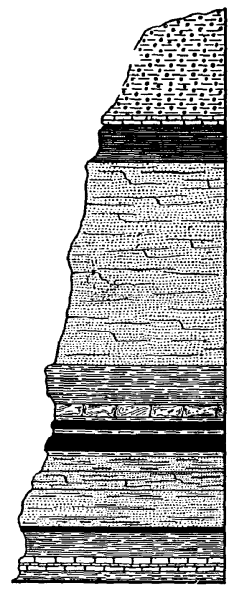

Figure 74. Section on Bulger Creek.

FEET. INCHES.

14. Drift $\ldots \ldots \ldots \ldots \ldots \ldots \ldots$ 15

13. Limestone, gray, fossilifer-

ous.................. I

12. Clay shales, variegated... 8

rI. - Sandstone, buff, soft, thinly bedded, and shaly...... 30

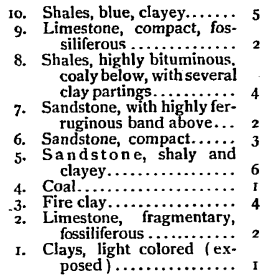

6

Farther up the Bulger to the county line no good exposures are to be seen. Occasional diggings or prospecting pits are noticed at various points, but evidently no coal of commercial value has been found.

North of De Soto a couple of miles on the Raccoon river, at Van Meter's mill and at various points between that place and Redfield, thin seams of coal are exposed in the bluffs. Mines have been opened on both sides of the river. Just above the mouth of the South Raccoon. and within a mile of Redfield a number of slopes have been made in the sidehill where a three foot vein of coal 
is exposed. 'Ten or a dozen feet above the coal is a thick bed of massive sandstone which a few hundred yards up the stream forms a precipitous cliff which rises out of the water and is known as "Hanging !Rock." At the south end of this place the section is as follows:

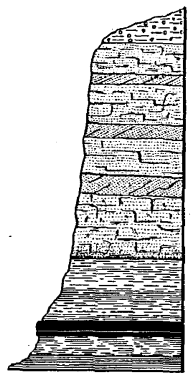

Figure i5. "Hanging Rock" Sec-
7. Drift................... 10

6. Sarldstone, massive rather fine grained, buff to dark brown in color $\ldots \ldots \ldots \ldots \ldots \ldots \ldots \ldots$ so

5. Shales, ash color to drab, somewhat sandy in places.......... 10

4. Coal......................... 2

3. Clay, drab color, fossiliferous....

Coal ..................... I Shale, somewhat sandy, drab, in places carbonaceous (exposed) 5

Redfield has long been known as one of the chief mining localities of the county. The earliest mines in the district were opened in this vicinity. In the valley of the South Raccoon coal has been mined quite extensively and a number of slopes and drifts have been opened from time to time. At the present time most of these mines have been abandoned or are not being worked. One of the principal openings is the Leeper shaft which was operated more than twenty years and was but recently abandoned. It was sixty-five feet_deep and worked conl two to four feet in thickness with an average of about three feet. It was located in Tp. 78 N., R. XXIX, W., Sec. 4, NW. qr., NW. $\frac{1}{1}$. At this place the section is : 


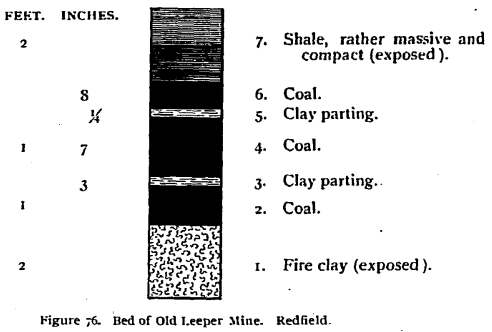

Not far from this place is the old Redfield mine a small drift that has been operated for a long time chiefly for local trade during the winter. Near the opening the following strata are shown:

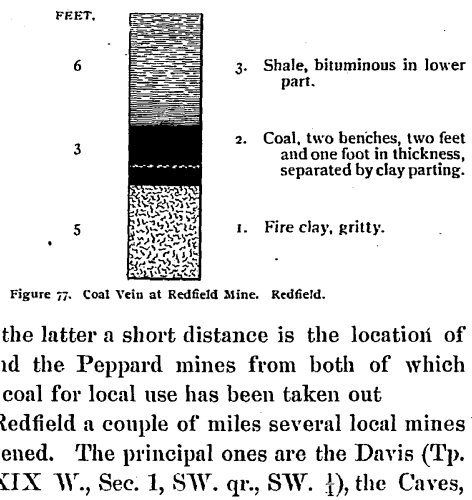

South of the latter a short distance is the location of the Clood and the Peppard mines from both of which considerable coal for local use has been taken out

East of Redfield a couple of miles several local mines have been opened. The principal ones are the Davis (Tp. 78 N., R. XXIX W., Sec. 1, SW. qr., SW. $\left.\frac{1}{1}\right)$, the Caves, 
the Thompson and the Hartman, all of which work in the same seam. The seam is two feet in thickness with a thin shale parting near the top. Numerous other mines were formerly worked in this vein, but those at present operated are worked chiefly during the winter.

Between Redfield and the west county line there are frequent exposures of Coal Measure deposits and also numerous openings from which coal has been taken out at various times. Coal is exposed at several places on Mosquito creek northwest of Redfield. Among the older mines which were operated here were the Parks and the Piatt mines, the former being 200 yards directly west of the latter. Both mines have only been worked to a small extent. On both sides of a small creek which empties into the Raccoon about one mile and a half above Mosquito several drifts have been opened, among which may be mentioned the Cotton and the Booth mines. The coal is about eighteen inches thick with good roof and appears to form quite an extensive layer. At the former mine the section is :

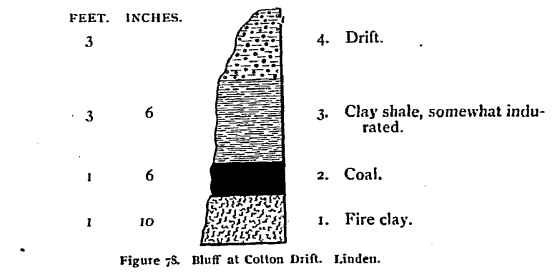

On the Raccoon, near an old mill site, is the Duck mine (Tp. 79 N., R. XXIX W., Sec. 32, N.E. q1., SE. $\frac{1}{1}$ ) where the coal worked was two feet in thickness. Considerable coal has been taken out. At the present time the 
exposure is greatly obscured but the following is the section of the bluff as given by St. John :

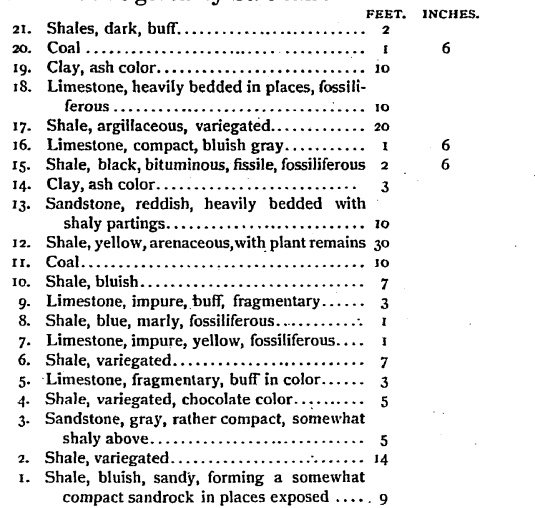

Two miles south of Linden, near the west county line, on the south side of the river is the Keeler mine (Tp. 79 N., R. XXIX W., Sec. 31, NE. qr., NW. $\frac{1}{4}$ ). The coal is eighteen inches thick with two shaly partings. The section of the coal bed is :

3. Sandstone (exposed )................. I

2. Coal, 8,4 and 6 inches, separated by thin clay partings...................... I

I. Fire clay $\ldots \ldots \ldots \ldots \ldots \ldots \ldots \ldots \ldots \ldots \ldots, 6$

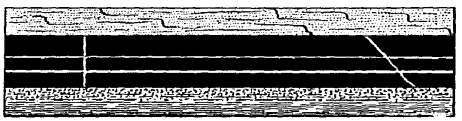

Figure 79. Clay Seams in Keeler Mine Linden. 
At this place two clay seams are exposed, one cutting the vein nearly vertically and the other at an angle of about forty-five degrees.

There are other mines in the vicinity of Linden but most of these are situated just over the line in Guthrie county.

\section{POLK COUNTY.}

This county has long been one of the most important coal producing districts in the state. The beds worked have an average thickness of about four and a half feet, though the workable seams vary in different places from two to seven feet. The more important mines of the county are located in the immediate vicinity of Des Moines where a large part of the product is used. The consumption of coal, however, at this place is considerably larger than the amount mined would indicate for much is shipped in from neighboring counties. Other groups of openings are situated in the southeastern corner of the county near Rumnells. Mines have also been opened along the eastern border of the district near Mitchelville and Altoona; in the southwestern part at Commerce; and in the vicinity of Polk City. A number of country banks are in operation in the extreme northwestern corner in the bluffs of the Des Moines river.

The first extensive mining in the county was begun near Fort Des Moines on the west side of the Des Moines river, where the coal crops out in the river bank about a mile above the Raccoon fork. Here as early as 1850 there was operated an opening known as Hall's coal bank. About the same time small drifts were also worked in the same vein at a number of points along the river. In the immediate vicinity of Hall's the Redhead mines were 
operated for a long time. Not far away, on the corner of what is now known as Sixth avenue and School street, the Rawson mine was worked for a number of years. Other mines were opened three miles northwest of the Forks in ravines leading down to the river.

On the south side of the Raccoon the existence of coal has been known ever since the time when Des Moines was a military post. A number of openings were made years ago. The best known of the earlier mines is the Van pit. The Sypher and Redhead shafts were also in the same neighborhood. These two pits developed into the Polk County and the Pioneer mines, which after being operated for more than twenty years were finally abandoned. At the present time the mining industry around Des Moines is carried on chiefly on the South side.

On the east side of the Des Moines river, coal mining was begun soon after the Hall bank was opened. At the south end of Capitol hill were a number of small drifts at the base of the bluff. 'They were known as the Reese mines. The coal vein is still to be seen in the cutting of the railroad a few feet above the track level. A shaft about forty feet deep and known as the Watson mine was subsequently put down in the same vicinity. For many years this mine supplied the railroads of the district with fuel. Another of these earlier mines was the Dahl, located a mile and a half north of the Watson shaft on the bank of the Des Moines river at Thompson's bend. East of the Capitol building a short distance is the location of another of the older mines, the Giant No. 1, recently abandoned. It was the most southerly of a number of shafts put down in this neighborhood. The section of rocks passed through is shown in the accompanying figure. (See figure 91.) The arrangement of the coal seams is 
typical of the East side mining district. Intil lately mining operations were carried on more extensively in this vicinity than anywhere else in the county. No less than a dozen large shafts have been opened from time to time.

It is commonly regarded by those living outside of the state that the coal deposits of Polk county are arranged in three separate beds which come so close together at Des Moines that they are readily mined as a single seam, no one of the three being thick enough for profitable working alone. This opinion has been widely quoted and has given the impression that the tripartite seam is the only one worked in the vicinity of Des Moines. In reality the vein is one of small importance, poor quality and seldom mined. All the coal now obtained at Des Moines comes from horizons from 60 to 130 feet below that of the seam in question. In the earlier days of the settlement of the region this "first" or "upper" vein was worked to some extent as it was easily accessible in the sides of the bluffs along the Des Moines river. The best exposures of the coal seam mentioned are now on the west side of the Des Moines river a hundred yards or more north of the mill dam at the foot of Center street. The section recently disclosed by road cuttings along the blufl' is shown in the accompanying figure (figure 80 ). It may be described as follows:

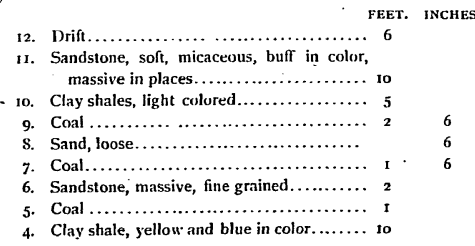




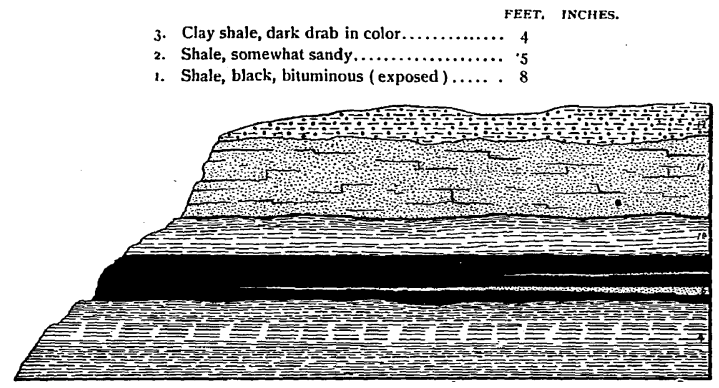

Figure ba. Bluff on Des Jloines River above Milldam. at City of Des Moines. Shows Coal Seam separated by Sand Bands.

The arenaceous layers, numbers 6 and 8 , thin out completely toward the south as shown in a ravine immediately north of the mill dam. Both beds, however, rapidly thicken in the opposite direction and in a distance of 150 yards the lower one of these has attained a thickness of more than three feet. Both seams of sandy material appear to be lenticular sheets intercalated in the coal vein which has a maximum thickness of over five feet.

In the immediate vicinity of Des Moines the strata exposed above the level of the river and open to view in mine shafts may be indicated in the following section :

26. Variegated clay shales FEET. INCHES.

25. Blue limestone, nodular, impure, weathering brown, fossiliferous. ................

24. Variegated shales................. s

23. Bituminous shale, with concretionary calcareous masses below, fossil bearing.... 3

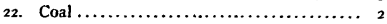

21. Light yellow and drab shales......... 7 
FEET. INCHES.

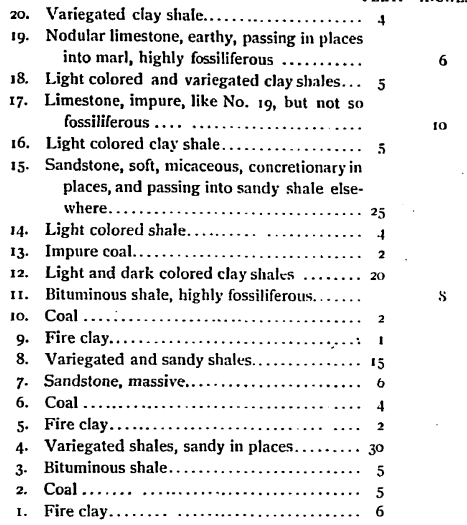

Numbers one to twelve are usually passed through in sinking shafts in south Des Moines. All numbers above ten are exposed above low water level in the Des Moines river. Numbers sixteen to eighteen are well shown in the river bed and in the adjoining bluff's on the south side of the railroad bridge on the Des Moines and Winterset branch of the C., R. I. \& P. railroad (Tp. 78 N., R. 24 W., Sec. 11, SE. qr., SW. $\frac{1}{4}$ ). Numbers thirteen to twenty are to be seen at several places in the sonth end of Capitol hill. Numbers thirteen to twenty-six have recently been well disclosed in the road cuts of Prospect Park in north Des Moines.

In Polk county it is customary to recognize three seams of coal. They are commonly called "first," "second" 
and "third" veins. These are the workable seams. Associated with them are others which in most cases thicken sufficiently in other places to be profitably mined. On the South side number ten of the general Des Moines section just given is the coal which is usually called the "first" vein, number six the "second" and number two the "third." On the east side number thirteen is probably the "first" vein. In neighboring localities the " first," "second" and "third" veins have still different stratigraphical positions as compared with those just given. It will be readily seen therefore that the naming of the different seams is in reality quite local in its application applying only to the shafts or borings which have been put down at particular places and that the same term does not necessarily refer to the same horizon. Besides the three veins usually encountered in boring it is not infrequent to meet with half a dozen or more minor veins.

In no case at present known is coal worked at a greater depth than 100 feet below the river level. The Coal Measures at this place are probably not less than three to four hundred feet in thickness and there appears to be but little doubt that prospecting to the depth mentioned would reveal the presence of coal in quantities even greater than the known supplies at present mined.

The same remarks also apply to other portions of the county especially in the southeast where mining is almost wholly confined to the bluff's above the river level.

The special development of the coal industry in the vicinity of Des Moines is probably due, in a great measure, to the excellent railroad facilities and the large local market afforded for the product. The coal is, probably, equally well developed in nearly, if not all, portions of the county. 
'The shipping facilities of Polk county are, perhaps, nowhere else in the state equaled. Seventeen lines of railway enter the district enabling the conl product to be loaded at the mines directly on the cars and shipped to all parts of the state, especially to the northwest. The local consumption is also much greater than anywhere else in the state and will continue to increase.

The consideration of the outcrops of coal and the various phenomena disclosed by the mines and borings may best be taken up by districts, the various drainage basins forming the most natural limits for the several areas.

Raccoon Valley.-There are a number of exposures of coal in the bluffs of the river but the mining of coal is now carried on entirely in horizons below water level. 'The general arrangement of the strata above the river are shown in the section on plate xir.

On the north side of the river there are a number of natural exposures showing coal seams to good advantage. At Commerce near the west county line small openings have been made in various places in a thin seam in the hills, but so far as known no mining has yet been carried on in these places. The coal now mined in this vicinity is chiefly at the Hulme mine which is about half a mile east of the town. The shaft is 100 feet deep; the vein from two to three feet in thickness. The dip is slightly to the northwest, somewhat undulatory. The seam is occasionally interrupted by "squeezes," sometimes from below, sometimes from above, but in no case are they of a serious nature. With the establishment of the rapidly growing town of Valley Junction, a couple of miles to the eastward, the development of the coal seams of this region will soon assume much greater importance than it has heretofore. 
East of Commerce for several miles there are no outcrops; though along $\mathrm{W}$ alnut creek there are a few exposures. Coal has been prospected for at different places but to no very great depth. On the Valley Junction road (Tp. 78 N., R. XXV W., Sec. 11) there is a vein of coal about two feet in thickness exposed half way up the hill. It is somewhat shaly above, and probably thickens northward.

A mile to the southeast, at the mouth of the Walnut, was formerly located tlie W $\mathrm{T}$ anut Creek mine. It was just four miles west of Des Moines, on the C., R. I. \& P. railroad. The shaft was about 140 feet deep; the vein from two to four feet in thickness, too thin for profitable working with the extensive top works which were erected. It thinned out rapidly northward but thickened south ward. The room and pillar plan was adopted for the south side of the mine where the coal was thickest; but on the north side the long wall system was in use.

A mile east of the latter place the shaft of the Two Rivers Coal Company was formerly located. From this mine considerable coal was taken out for the city trade and for shipment over the C., R. I. \& P. railroad. The ground is now occupied by the Des Moines Brick Works.

Still farther to the eastward at the south end of Terrace Hill a small coal pocket is shown in a railroad cutting ( figure 81). The section is as follows:

9. Shale, light colored. (exposed)............. FEET. INCHES

8. Limestone, impure, nodular, weathering brown and containing fossils.............

7. Shale, argillaceous, white and drab......... 5

6. Limestone, nodular, like No. 8 , but containing fewer fossils.......................

5. Shale, dark drab below, light colored above. 4

4. Shale, bituminous, fissile, with coaly streaks. 2

3. Coal ............................. 3

2. Shale, light colored, somewhat sandy....... 6

I. Sandstone, somewhat shaly, concretionary in places, exposed above track level...... 6 


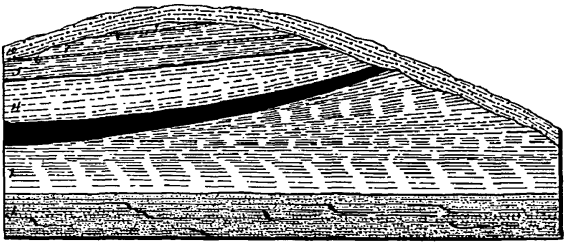

Figure 8t. Terrace Hill Section. Des Moines.

On the south side of the river below Commerce there are few exposures, until within about four miles of Des Moines. The first opening met with is a small drift a few hundred yards west of the Rose Hill shaft. Apparently not much coal has yet been taken out. A short distance east of the drift is a recent railroad cutting. At this place (Tp. 78 N., R. XXIV W., Sec. 18, NE. qr., SW. $\frac{1}{4}$ ) the following section is exposed :

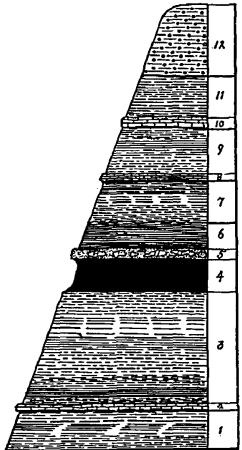

Figure 82. Railroad Cutting near Rose Hill Mine. Four Miles West of Des Moines.
FEET.

12. Drift $\ldots \ldots \ldots \ldots \ldots \ldots \ldots \ldots \ldots \ldots$, 10

I I. Clay shales, red and drab, variegated 6

10. Limestone, earthy, nodular........ $1 / 2$

9. Shales, variegated............ 5

8. Limestone, impure, nodular....... $1 / 2$

7. Clay, yellow and drab, variegated... 4

6. Clay shale, dark drab, somewhat bituminous ................... 2

5. Ironstone, black, nodular........... I

4. Coal, impure................. 3

3. Clay shale, hard, drab, somewhat sandy in places ............... 15

2. Limestone, nodular.

I. Clay shale, blue (exposed to track

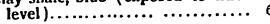


Rose Hill mine is situated on the Des Moines and Kansas City railroad. It is at the foot of the bluff and ninety feet deep. The vein is from two to four feet in thickness.

For a couple of miles east of Rose Hill coal has been prospected for along the bluff. The first place of importance is the Coon Valley mine which is located on the South side about half a mile west of the Seventh street bridge over the Raccoon river. It is on the Des Moines and Kansas City narrow gauge railroad; formerly also loading coal on the C. G. W. tracks. The shaft is 120 feet deep and is situated on the river bottom near the foot of the bluffs. The coal is four to seven feet thick. The seam is somewhat undulatory and is the "third" vein. Thirty-five to forty feet above is the second vein about four feet in thickness. Fifty feet farther up is still another seam from three to four feet thick.

A short distance to the eastward is the location of the old Pioneer mine on the south bank of the Raccoon river at the end of Seventh street bridge. The Pioneer mine was recently abandoned, after having been worked for twenty years, being one of the oldest coal pits in the county and for a long time the largest operated. It was first opened as a drift in a seam just above the water level. After working some time a shaft 150 feet deep was sunk at the same place into the "third" vein, the "second" seam at this point being too thin to be operated. The coal was from four to seven feet in thickness, somewhat undulatory or rolling. Some of the entries were driven southward more than a mile from the bottom of the shaft. The mine was operated by the room and pillar method, but the coal being rather soft many of the pillars were crushed under the great superincumbent 
weight and from time to time allowed the roof to settle down to the floor. Considerable coal was taken out on the north side of the shaft under the river but the coal in this direction soon became too thin for profitable working.

Just west of the shaft last mentioned a deep ravine opens ont to the southward. In its sides a number of openings for coal have been made at various points, but at present most of these diggings have been abandoned. A mile to the southward of the old Pioneer shaft is the Proctor mine. The shaft is $\mathbf{1 9 7}$ feet deep. Four seams are shown in the section, only the lower two, however, being operated at present. The coal of the lower vein, the "third," is from three to five feet in thickness. The details of arrangement of the various layers are :

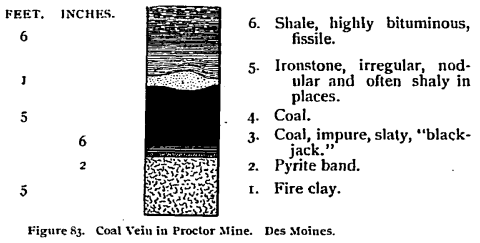

The next vein is about thirty feet above and is three to four feet thick. Thirty-five feet higher is still another seam which is about two feet in thickness. The lower vein is somewhat undulatory and presents good illustrations of what the miners term "troubles" or "horsebacks." A section of one of these is shown in the accompanying figure (84). The coal rises in a low fold to 
a height of fifteen or twenty feet above the rest of the seam on either side. The grentest inclination of the seam is from fifteen to twenty degrees. Near the top of the fold on one side the seam which is five feet in thickness is suddenly reduced to one-half that neasurement through

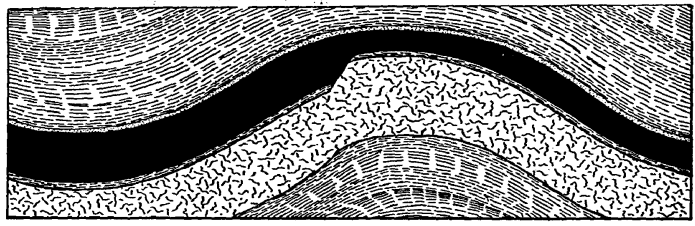

Figure 84. "Horseback" in Proctor Mine. Des Moines.

an abrupt rise in the floor forming a small fault. Over the top of the fold the coal continues to be quite thin but on the opposite side becomes slightly thicker.

Half a mile east of the Proctor and directly south of the Pioneer is located the Bloomfield mine (Tp. $78 \mathrm{~N}$., R. XXIV W., Sec. 16, SW. qr., NE. $\frac{1}{4}$ ). When first opened it was a small shaft known as the Carlston and Lund mine. The "first" vein only was worked. The coal seam was so badly eut up by old preglacial channels that the opening was finally abandoned. When the Bloomfield company took up work the shaft was sunk to the "third" vein, which has a thickness of from four to six feet. The section of layers above and below the coal is:

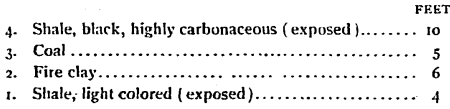




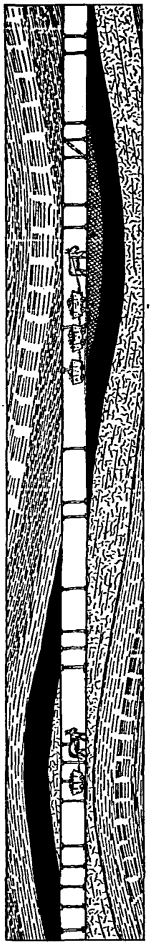

The coal is mined on the room anr pillar plan. The seam is quite undulatory in character the difference in level being often as much as twenty to twenty-five feet in fifty or seventyfive yards. As the grade in the entries has to be kept as low as possible in order that the loaded cars may be drawn easily considerable expense is ineurred in "leveling up" the passage ways, "shooting" down the roof in some places and filling up below or cutting out the floor. The entrances into the old rooms along an entry are thus scattered at various distances above or below the present track grade. In some cases the entries have a height of ten to fifteen feet. The undulatory nature of the coal bed enables the layers both above and below to be examined often for a dozen or more feet.

A number of small faults occur in the mine but the throw is seldom more than three or four feet. The hade varies from $30=$ to $(30=$. None of these, however, are great enough to seriously interfere with the working of the vein.

Associated with the coal bed are numerous lenticular masses of ironstone. They vary in size from a few inches to ten or twelve feet horizontally, and up to six 
feet vertically. 'The smaller ones are commonly called

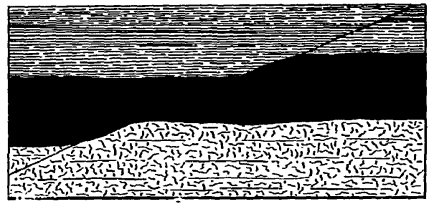

Figure 86. Fautt in Bloom field Mine. Des Moines.

"nigger heads." These segregations occur in all parts of the coal seams, but they are most abundant in the roof

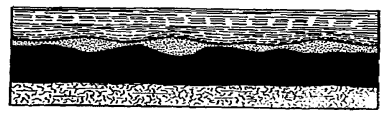

Figure 87. Ironstone Band and Roof of Coal Seam, Bloomfield Mine. Des Moines.

and upper surface of the coal, where they are often so close together as to form an almost continuous layer. It

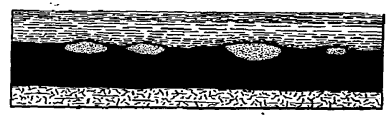

Figure 88. Ironstone Nodules in Roof of Coal Bed. Bloomfield Mine. Des Moines.

is common for the nodules in the upper part of the coal to project upwards above the top of the scam, of ten two to

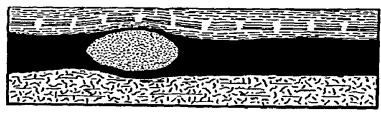

Figure S9. Ironstone Mass, in Coal Bed of Bloomfield Mine. Des Moines. 
three feet in case of the large masses. 'They arc covered usually by a few inches of carbonaceous material. Both above and below each nodule the coal is strongly laminated, indicating that the bed of coal had diminished considerably in bulk since its original burial by the overlying sediments. These various phases are illustrated by the accompanying diagrams. (Figures 87 to 89.)

The Eureka mine is situated about a mile east of the Bloomfield on a switch of the C., R. I. \& P. railroad, The shaft is at the foot of the bluff and is about 160 feet deep. The thickness of the coal is from four to six feet. The coal is mined on the room and pillar plan.

The Des Moines mine in Sevastapol is half a mile east of the Eureka. It is a shaft 105 feet in depth, with coal four to six feet in thickness. Just south of the last is the Union mine, a shaft 150 feet deep. Two veins have been worked. The coal from the "second" being long since removed the "third" seam was reached by sinking the shaft deeper. The coal has an average thickness of four feet, and is now worked entirely upon the room and pillar plan.

The old Polk County mine recently worked out was situated on the South side about one mile east of the Pioneer. When first opened it was known as the "Sypher" mine. The shaft was 120 feet deep and located on the bluff about half a mile from the river. This mine was in operation for more than twenty years. In common with several other mines in the vicinity the output was loaded directly on the cars which ran over a switch from the Des Moines and Winterset branch of the C., R. I. \& P. railroad. For a long time the coal was taken out from the "second" vein until finally, the territory owned by the company having been worked out, the shaft was extended downward to the 
"third" seam. The "second" vein was said to have a thick sandstone roof. In places the coal was cut through by some ancient water course, the channels of which were filled with logs and other driftlike material as shown in figure 21 (page 18t). These cuttings appear to be preglacial and the deposits filling them glacial débris. The lower seam called the "third" is the same as in all seven of the mines just mentioned, and with the exception of the Proctor they are all connected underground.

The Pleasant Hill mine was a small shaft in the bluff, a short distance south of the Union. The shaft was eighteen feet in depth, with four feet of coal.

Just east of the Union is the Van Ginkle mine. The shaf't is about seventy-five feet deep. The coal is the "second" vein and has an average thickness of four feet, the maximum measurement often being over five feet. The room and pillar plan is in use. The roof is a heavy sandstone having a thickness in places of upwards of fifteen feet. Many of the rooms are fully 200 feet long and twenty-five to thirty-five feet wide without timber supports.

A fault of considerable throw is said to trend sontheast between the Des Moines and the Van Ginkle. The entry in the former mine where the slip occurs was not open at the time of writing and the extent of the throw could not be determined.

The Co-operative mine is situated on the top of the bluff a short distance south of the Van Ginkle mine. 'The shaft is 125 feet in depth. The Pittsburg mine was also in the same vicinity. It was a small shaft which was abandoned some seven or eight years ago. Half a mile east of the Polk County pit the Eclipse mine was located at the base of the very steep bluff and a short distance 
west of the present bridge of the Des Moines and Winterset branch of the C., R. I. \& P. railroad. It was worked by the room and pillar method and was at one time one of the most extensive mines in the district:

Des Moines Valley above the Raccoon Fork:-In the extreme northwestern corner of the county numerous small drifts have been made for several miles along the river. There appear to be at least two seams of coal above the water level in this part of the county and there are probably other veins lower down. The principal mine now operated in this vicinity is the Strong shaft, just over the line in Dallas county. It is forty-five feet deep and works a vein of coal two to two and a half feet in thickness. The bluff just beyond the west county line shows :

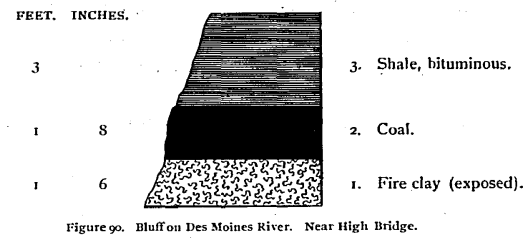

The largest pit in this part of the county is the Polk City mine, which is located a mile north of that town. The shaft is 238 feet in depth. The coal is about four feet thick and is mined on the long wall plan. The seam is in reality composed of two, which are two and a half feet and one foot in thickness and are separated from each other by an eight-inch layer of black shale, which has to be taken out in working the coal. 'The roof is bituminous shale and is very good. The vein is slightly 
undulatory. The coal is used largely for local use and could be shipped over the $C$. \& N. W. railroad.

Between Polk City and Des Moines there are no mines of any consequence until the immediate vicinity of the capital is reached, though small country openings and drifts have been operated in the bluff's at numerous places. Prospecting has been done in the valley of Beaver creek. Four miles north of Des Moines on the west side of the river, and about a mile below the mouth of Beaver creek there has recently been sunk a new shaft-the West Riverside. This mine is located at the foot of the bluff. It is 145 feet deep and operates a vein of coal six feet in thickness. Six feet above the coal worked is a thinner vein about two feet in thickness which will probably be operated after the coal below is worked out. A short distance directly south, on the farm of Judge Nourse, another shaft has been put down lately. This is the Keystone mine. It is situated on the top of the bluff and is 142 feet in depth. The coal averages five and a half feet in thickness and has a good roof of bituminous shale twelve feet thick. A mile nearer the city are several old openings in the ravines leading down to the river. Some years ago a shaft and several drifts were operated here. At the shaft which was in the ereek just south of the Close place, a seam of coal of rather inferior quality is exposed in the hillside. It is about two feet thick.

Directly across the river on the east side and direetly west of Highland Park is the plant of the Flint Brick Works. A shaft has been prit down by the company to the depth of 122 feet. The mouth of the shaf't is only a few feet above the water level of the river. The coal is five feet in thickness. Above the seam now worked are three other veins which though somewhat thinner will 
probably be developed after the lower vein is worked out. A quarter of a mile directly west of the Flint shaft is the Oak Park mine which is $\mathbf{1 3 0}$ feet deep with coal three and a half feet in thickness. There are three veins above the one worked, as in the mine last mentioned, the uppermost of which is four feet in thickness and is about on a level with the low water mark in the Des Moines river. 'This seam has been reached by means of a slope at a number of places in the vicinity, but as yet comparatively little coal has been removed.

In the top. of the hills east of the brick plant a threefoot seam of coal is often struck in sinking wells. The vein lies at a depth of forty feet below the surface. Between this point and the dam two miles below coal is exposed at a number of places along the river bluff and as already said was mined years ago.

In east Des Moines considerable coal occurs east and northeast of the Capitol building. At the south end of Capitol hill the old Watson shaft forty feet in depth was operated some years ago. Immediately east of the Capitol is located the abaindoned shaft of the Giant No. 1. From the section it will be seen that there are three veins of workable coal. The "first" is usually, however, rather poor in quality and seldom worked to any great extent. At this place the " second" seam was mined for a long time but finally this was abandoned and the shaft sunk forty feet deeper to a third and thicker vein. The section of strata passed through in sinking the shaft is as follows : 


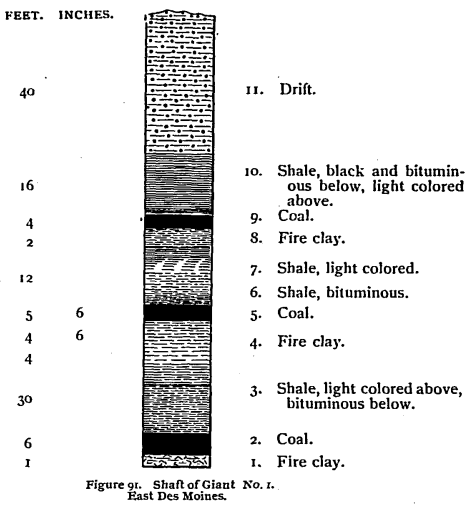

In running eastward a short distance from the shaft there is encountered a weak thin roof which is immediately overlaid by gravels and sands through which appears to flow an underground current of water of considerable extent. A number of mines in the neighborhood have been flooded and abandoned on account of the falling of the roof; but the operators of this pit removed only half the thickness of the coal leaving the other half to protect the shaly covering.

Half a mile northwest of the latter mine was located the shaft of the Giant No. 2, which was also operated for many years and produced a large amount of coal. A short distance directly north of the Giant No. 2, is the Garver, a shaft 118 feet deep. Both the upper seam and the "third" vein are worked. As 
in the Giant No. 1, the heavy water vein is immediately over the coal so that great care is taken to prevent the roof from becoming defective. 'The coal varies from four to seven feet in thickness. The mine has very recently been abandoned but the operators expect to soon put down another shaft a short distance away which will still enable them to finish working out the old mine and at the same time give them a large amount of new territory.

The A tlas shaft was located a quarter of a mile directly east of the Garver. It is 100 feet in depth. Two reins were worked. There is a considerable dip to the seams in places making the haulage from the entries somewhat difficult. Directly north of the Garver mine were situated the shafts of five other mines, the Watson, Miller, Extra, Standard No. 1, and Diamond. They were all operating veins with a slight dip to the eastward and with a gradual increase in thickness in the same direction. These mines had worked only a short distance from the bottom of the shaft when water bearing sands and gravels which overlie the coal were encountered. Owing to carelessness the roof gave way, the pits were flooded and finally abandoned. The mines just mentioned shipped the greater part of their product over the Northwestern railroad which ran long switches down from its Des Moines and Ames branch.

Another mine which deserves mention in the present connection is within three miles north of the Garver on the C. \& N. W. railroad, a mile south of Saylorville station. It is the new Des Moines mine recently opened and is now operated quite extensively. A mile and a half northeast of the Garver are two other mines, the Maple Grove shaft on the C. G. W. railroad, 105 feet in depth 
with coal three to four feet in thickness, and the new Union shaft which is taking out considerable coal.

Des Moines Vulley below the Fork:-On the south side of the river at Sevastapol there is a group of mines, of which the Eclipse is the largest. A number of prospecting holes have been put down for coal with more or less success. Several seams are also exposed in the river blufls. Directly north of Avon a number of country banks have been operated for many years past. Lately coal has been mined at the Coal Hill shaft, known also formerly as the Coon Valley No. 2, and the Manbeck. It is located on the Des Moines and Winterset branch of the C., R. I. \& P. railroad. It is near an old channel of the Des Moines river, and was formerly operated by a shaft but at present a slope has been opened through which the coal is now brought to the surface. There are two veins being worked besides which a number of thin seams are known. The distance between the two workable seams varies from twenty to thirty feet. The greatest thickness of the lower seam is about five and one-half feet, the average thickness nearly three. While somewhat undulatory the vein nevertheless has a slight southerly dip, approximately three to four feet in a hundred. The floor of the lower seam worked is a fire clay said to have a thickness of twenty feet. The roof is a hard clay shale containing much clay ironstone in the form of nodules, lenticular masses and sheets. Small irregular clay seams and faults cut the veins in many places.

The following is a detailed section showing the relations of the various coal seams at the Coal Hill mine: 


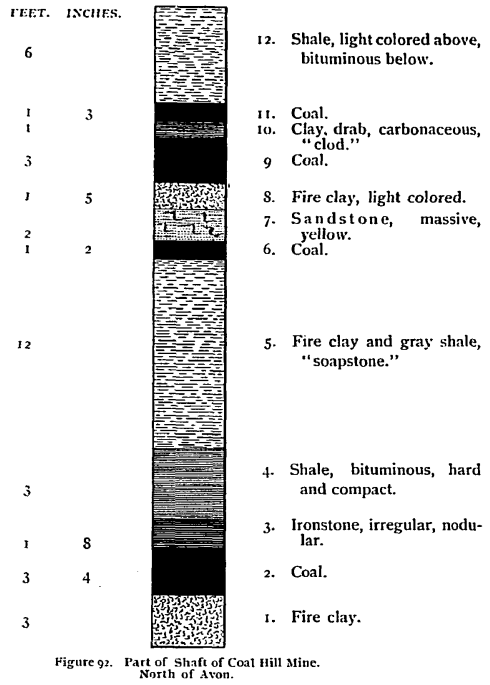

A short distance farther to the sontheastward the railroad has cut into the sidehill exposing an almost continuous section for a quarter of a mile or more. 'Two coal seams are shown and ledges of brown sandstone are conspicuoris. The vertical sect ion is shown in figure 93.

Directly enst of Des Moi nes near Four Mile the first mine met with is the Gibson mine which is located on the main line of the C., R. I. \& P. railroad. It is a shaft 105 feet deep with coal four and one-half to five feet in 
thickness and quite regular. A half a mile or more east of the Gibson on the same railroad is the Christy mine in

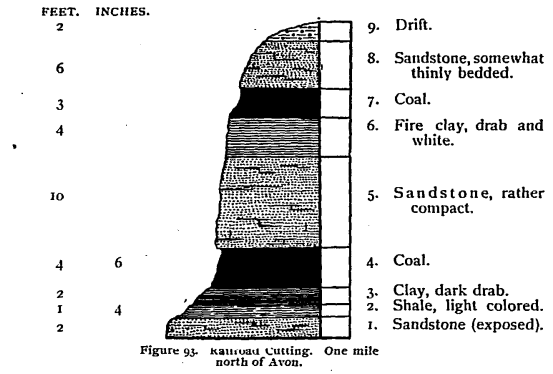

the valley of little Four Mile creek. It is a shaft 115 feet deep with coal three to five feet in thickness.

A mile to the southeast of the latter is the Carbondale shaft, which is 108 feet deep with coal four feet in thickness. The roof is very hard and compact. The product is shipped over a long switch of the C., R. I. \& P. railroad. Northeast of the Carbondale at a number of places near Rising Sun country banks have been operated for many years.

The Wabash mine is situated at Hastie, five miles southeast of Des Moines, on the Wabash railroad. The shaft is $\mathbf{1 0 0}$ feet in depth; thickness of coal four feet. Two other shaft mines, one 100 feet to the west and the other a short distance to the east, were operated until quite recently in the vicinity. A shaft was also formerly worked in the hill near by. 
A mile east of the latter is a new mine of the Iowa Coal Company which has recently been opened in the valley of a small creek. The shaft is sixty-five feet deep; the conl three to three and one-half feet in thickness. A railroad cutting at this place, which is about on a level with the mouth of the shaft, shows the following section :

FEET. INCHES.

9. Drift............................ 4

8. Shale, sandy, yellow................. $3^{0}$

7. Slıale, bituminous $\ldots \ldots \ldots \ldots \ldots \ldots \ldots \ldots, 3$

6. Coal.......................... 3

5. Clay, white and ash colored............. 2 .

4. Coal, impure....................... 6

3. Shale, yellow and white.............. 4

2. Coal, impure..................... 8

I. Shale, dark drab (exposed) $\ldots \ldots \ldots \ldots \ldots 6$

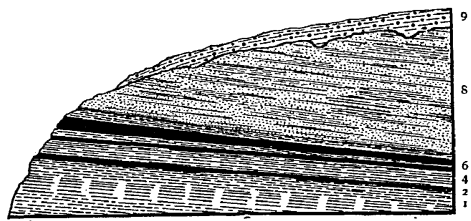

Figure 94. Railroad Cutting. One Mile Ezst of Hastie.

Between the last point mentioned and Rumnells very little mining has been done although coal is well exposed in a number of places in the bed and bluffs along the river. Country banks have been operated at various places.

About half a mile west of Rumnells in the bluffs of Mud creek a short distance from the Wabash railroad is situated the Logan mine. It is a shaft forty feet deep; the coal averages four feet in thickness. At the north 
side of the town is the Runnells mine. The shaft is fortyfive feet deep with coal four feet in thickness. Near by is the Stoughtenberg drift. The coal is about four feet in thickness and is shipped over the Wabash railroad. Five hundred yards east of Runnells postoffice is the Camp mine a small slope also shipping its output over the Wabash.

The Acme mine, formerly called the Rumnells slope, is located about half a mile east of the town of Runnells, sixteen miles southeast of Des Moines on the Wabash railroad: It is a slope in the river bluff. The seam is four feet thick, and slightly undulatory. The roof is black shale and as a rule very good. The section of the coal bed is :

FEET.

3. Shale, bituminous, fossiliferous................ 6

2. Coal...................................... 4

I. Fire clay (exposed) $\ldots \ldots \ldots \ldots \ldots \ldots \ldots \ldots \ldots \ldots, 3$

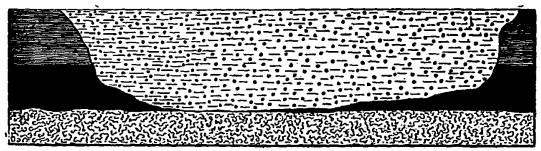

Figure os. Preglacial Channel in Coal Bed at Acme Mtine. Runnells.

Between the air shaft and the opening of the mine there is an area in which the coal has been removed. It is an old preglacial channel which is now filled with drift materials, including numerons large granite boulders. The width of this channel is about sixty feet. (Figure 95.)

In the southeastern corner of the county, along the line of the Wabash railroad, there are numerous exposures for several miles from the east county line. About a mile east of Runnells station one of the railroad cuttings shows: 


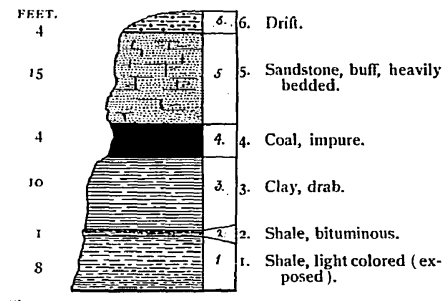

Figure 96 . Railroad Cutting near east County

Line, below Runnells.

The Altoona mine was located on the C., R. I. \& P. railroad, just west of Altoona station, eleven miles east of Des Moines. The shaft is 215 feet deep. There are two seams of coal which are about fifteen feet apart. The upper one is about eighteen inches and the lower four feet thick. The first of these is overlain. by fifteen feet of massive sandstone, which forms an excellent roof. The coal was of very good quality and much harder than the average mined in the county. The strata passed through in the sinking of the shaft are shown in the following figure :

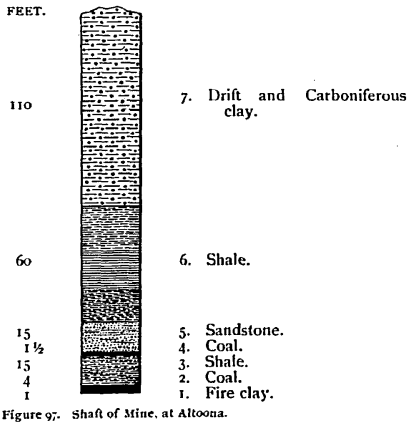


The vein was slightly undulatory, but had a general dip to the southward. Both east and west of the shaft the coal became thinner, but to the south the coal thickened. The shale forming the roof was twelve feet in thickness, but cracked readily as soon as the coal was removed thus requiring close propping. It was finally allowed to fall in places and the water came in, rising in the shaft to a height of 150 feet.

\section{JASPER COUNTY.}

With the exception, perhaps, of several small areas in the northeastern part, Jasper county is entirely underlain by Coal Measure strata. The county lies on the eastern edge of the Iowa coal field, the Lower Carboniferous rocks being exposed at various places near the surface immediately to the east and north. The Saint Louis limestone, the upper member of the Lower Carboniferous, crops out in the beds of the Skunk and the Des Moines rivers in Mahaska and Marion counties, within five miles of the Jasper county line. In a number of places in the central part of the county. at depths of 125 to 150 feet limestone has been reported to have been encountered in drill holes in prospecting for coal. The Coal Measures in the eastern part of Jasper are comparatively thin and probably nowhere over 150 feet in thickness. Along the extreme western border of the county in the vicinity of Mitchellville this formation may be fifty or seventyfive feet greater in thickness. The northern and eastern portions of the county are deeply covered by drift deposits which greatly obscure the general character of the stratified rocks. In the Coal Measures of Jasper sandstone beds are exposed at many places, and in the southern part of the county appear to be continuous with 
the great Redrock sandstone so well exposed on the Des Moines river six miles south of Monroe.

Until recently Jasper county has not produced much coal and the product mined has been only for local use. Within the past few years, however, extensive operations have been carried on near Newton and Colfax which are now the most important mining points in the county.

Jasper county now enjoys good railroad facilities, two lines and branches of the Chicago, Rock Island \& Pacific pass almost entirely across the county, besides branches of the Iowa Central and the main line of the Chicago Great Western. From these railroads short branches have been built to some of the leading mining districts and considerable coal is now shipped.

In the extreme eastern part of the county along the North Skunk river a couple of miles above Lynnville a number of mines have been operated for some years. The largest mine in this vicinity is called the Black Oak shaft. There are three veins of coal at this place the upper being from two to four feet, the second twenty-two inches and the third sixteen inches thick. The mine is located in Tp. 79 N., R. XVII W., Sec. 34, SE. qr., NE. $\frac{1}{4}$. The section of the shaft is shown in figure 98 .

Other mines in this vicinity are the Meredith, Spark, and Martin openings, besides several smaller ones.

The mining at Newton is done chiefly three miles southwest of the town on a branch of the C., R. I. \& P. railroad. There are two veins of coal, the upper one about one foot in thickness and the lower from four to six feet.

The Conn and Murdock Coal Company (Tp. 79 N., R, XIX, W., Sec. 8, NE. qr., $\mathrm{NW}, \frac{1}{4}$ ) has a mine which is a shaft thirty-eight feet deep, worked on the room and 
pillar plan. 'The vein dips slightly to the southeast. 'The Snooks Mine (Tp. 79 N., R. XIX W., Sec. 16, SE. q1., SW. $\frac{1}{4}$ ) is a shaft sixty feet deep with a vein of coal four to six

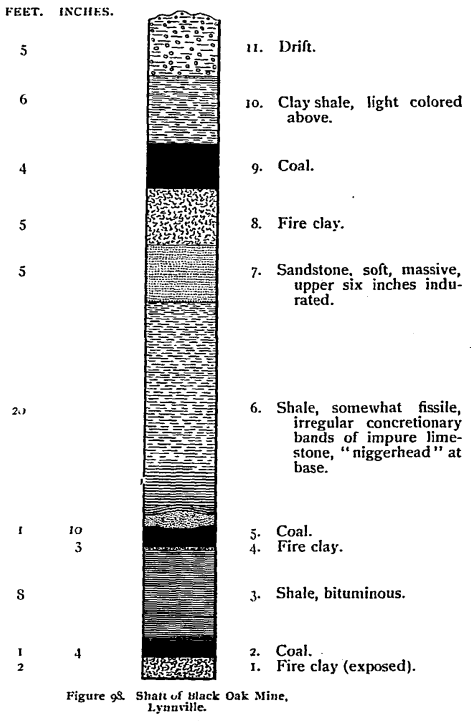

feet in thickness. The roof is rather poor in places of ten rendering it necessary to leave a thin layer of coal to protect it from exposure to the air. The coal bed is quite 
undulatory but has a slight general dip to the sonthwestward.

The Lister mine is near the Conn and Murdock shaft (Tp. 79 N., R. XIX W., Sec. 8, NW. qr., NW. $\frac{1}{4}$ ). It is a country bank, though shipping some coal. The vein dips to the southwestward.

The Carson mine is a slope immediately northwest of Coal Siding ( Tp. 79 N., R. XIX W., Sec. 9, SW. qr., NW. $\left.\frac{1}{4}\right)$. The shaf't is forty feet deep and passes through three veins of coal, the lower varying from three to five feet in thickness. There is no noticable dip.

The Welch mine is situated 200 yards directly north of the Carson mine. The coal worked is the same vein as that mentioned as occurring in the other mine and is from four to four and a half feet in thickness. The Riley mine is located a short distance sonth of Coal Siding. The coal is three and a half feet thick with good shale roof; ten feet above this vein is another layer of coal, too thin for profitable working.

Just east of the Welch mine is another small bank operated by Thomas Snooks. The greatest thickness of the coal at this place is twenty-eight inches. Davidson No. 1 is a half a mile southeast of Coal Siding ( $T$ p. 79 N., R. XIX W., Sec. 16, NE. q1., SE. $\frac{1}{4}$ ). It has been worked for twenty years, usually, however, only in the winter. Twelve or fifteen men are commonly employed. The shaft is about forty feet deep, the coal seam mined being from four and a half to five feet in thickness. The vein is somewhat undulatory with quite a number of small slips and faults. In the main east entry an interesting series of faults were encountered. In traversing a distance of 300 yards six parallel faults running from north to south were crossed. The coal in each case 
drops on the east a distance varying all the way from six inches to three and one-half feet. The lines of slip have an angle of about forty-five degrees. The total displacement was probably in the neighborhood of ten feet.

The Davidson No. 2 is a half a mile north of No. 1. The strata passed through in sinking the shaft are practically the same as in No. 1, except that two reins of coal appear about eighteen feet below the first. The first vein is only ten inches thick and appears to be the same as that mined in No. 1. The lower vein varies from a few inches to four and a half feet in thickness. The section is :

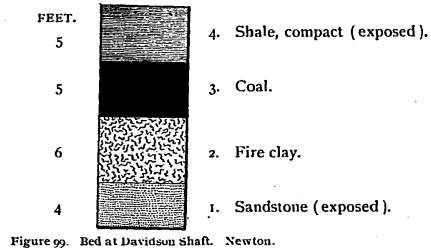

The Conn mine (Tp. 79 N., R. XIX W., Sec. 3, SE. qr., N W. $\frac{1}{4}$ ) is located a mile and a half directly south of Newton. The coal worked is four feet in thickness. There is also a thin vein nine feet above.

Near the southern border of the county, three or four miles east of Monroe, is a mining camp called Draper. At this place considerable coal has been mined, near the center of section 26 ( $\mathrm{T}_{\mathrm{p}}$. $78 \mathrm{~N}$., R. XIX W.), in the Barnes and Mitchell slopes. Half a mile directly west (Sec. 27, NE. qr., SE. $\frac{1}{4}$ ) is the Danks mine. There are two veins of coal in this neighborhood, the lower one being worked almost altogether. It is three to five feet in thickness and has a slight dip to the southwest. A 
mile and a half to the southwest and about two miles and a half directly east of Monroe is another group of mines. 'I'he Edward slope (Tp. 78 N., R. XIX WT., Sec. 33, NE. q1., NE. $\frac{1}{4}$ ) is, perhaps, the most important. There are two seams of coal about ten feet apart. $A$ short distance south of this mine is the Sloaw slope. The Jasper Coal and Railway Company have several mines in this vicinity, two of which are shafts about thirty-five feet deep. The conl averages four feet in thickness, and is mined on the long wall system.

West of Monroe four or five miles on Calhoun creek a number of drifts are seen in the hillsides. There are also a half dozen or more country banks a few miles west of the last named place and three to four miles south and southwest of Prairie City.

Northwest of Prairie City and about one mile east of Mitchellville is the Cooke shaft which is ninety feet deep. There are three veins of coal, one foot, eight inches, and four and one-half feet thick. The beds are somewhat undulatory and dip slightly to the northeast. The roof is dark colored shale which has a thickness of fifteen feet. The strata at the bottom of the shaft shows:

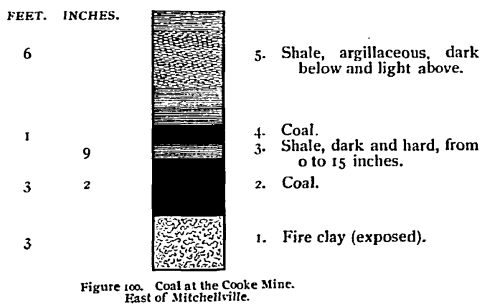


Along the C., R. I. \& P. railroad a couple of miles northeast of Colfax several small mines have been opened along the Skunk river. The principal mining in the Colfax district is a mile and a half northwest of the town. Here the Jasper County Coal Company have sunk a number of shafts and opened up an area of considerable size. Three veins of coal are present. Shaft No. 3, which has recently been opened, is about 100 feet deep with the coal from four to five feet in thickness. This is the first vein, the two others below being too thin for profitable working as long as the thicker coal above holds out. The coal seam shows the following:

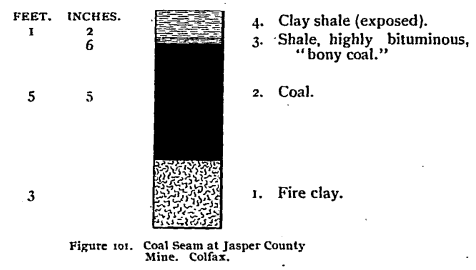

Four miles northwest of Colfax at a mining camp called Oswalt a number of shafts have been put down. The Diagonal Coal Company had four mines, the Jasper Coal and Mining Company three, Black Heath, Pittsburg Star, and Little Diamond one each. All of these have been worked out and abandoned.

\section{POWESHIEK COUNTY.}

Poweshiek county lies at the extreme eastern edge of the Iowa coal field, yet at least one-third of its area is 
underlain by Coal Measure strata. There are probably also numerous small basins or pockets scattered over the county which will eventually yield workable coal. The entire county, however, is so decply covered with drift materials that exposures of stratified rocks are very few in number and are confined almost entirely to the southwestern corner of the comty. It is owing chiefly to the great thickness of glacial débris that prospecting for coal has not been carried on to such an extent as it ordinarily would be in other districts.

Along the Skunk river in the extreme southwestern corner of the county the Lower Carboniferous limestone is exposed at a number of places in the river banks above the bridge of the Iowa Central railroad. Outcrops of black shales and ferruginous sandstone of Coal Measure age are also seen at many places along the same stream as far as the west county line and also in some of the small creeks in the same region. The only mining yet known to have been undertaken has been along Buck creek in Union township. In the bluffs and bed of this creek there are frequent outcrops of Coal Measure strata. It is reported that exposures occur at short intervals along the stream for a distance of six or eight miles. As long ago as 1868 Smith and Barrowman opened a mine on this creek about six miles southeast of Searsboro. Although the outcrop of coal was only eight inches in thickness; a drift was carried into the hill for a distance of 150 feet. The coal instead of becoming thicker became thinner. The black shale above the coal is really much thicker than might be inferred at the mouth of the drift. Fifteen yards away this shale is exposed by recent landslides and has a thickness of a dozen or more feet. The section at the opening is shown in figure 102 . 
Prospecting for coal has begun recently at various points in the southwestern part of the county. At Searsboro in the hill just west of the village two drill holes have

FEET. INCHES.

2

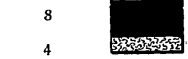

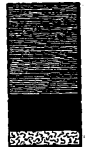

2. Coal.

I. Fire clay (exposed).

3. Shale, bituminous, (exposed).

Figure 102. Coal at Smith and
Searsboro.

been sunk to a depth of 100 feet revealing thin seams of coal. A number of wells sunk a few miles to the southward have also encountered small layers of the same material. About a mile east of the Central Iowa railroad bridge over the Skunk river a boring has shown a coal vein one foot in thickness about fifty feet below the surface.

On the south side of Skunk river about a mile above the bridge of the Central Iowa railroad is the location of the old Petit mine (Tp. 78 N., R. XVI W., Sec. 36, SW. q. NW. $\frac{1}{4}$ ). This was a drift opening worked some years ago and supplied a considerable amount of fuel to the neighborhood. The vein was sixteen inches in thickness. and quite regular. The section of the bluff is shown in figure 103.

A short distance below this opening was the Watson drift which was worked for a short time. Other small drifts are also reported to have been opened in the ravine a short distance back from the river.

Traces of coal have been reported from points a short distance south of Montezuma, in the vicinity of Deep river in the southeastern part of the county.

In Keokuk county, at Thornburgh, coal has been mined for a number of years within two or three miles of 
the Poweshiek county line. This is only a half a dozen miles from the What Cheer district, which includes some of the largest and most important mines in the state.

Five miles directly west of Searsboro, in Jasper county, a number of mines have been operated in a vein of coal having a thickness of from two to four feet. The chief mine in this vicinity is the Black Oak shaft, the coal
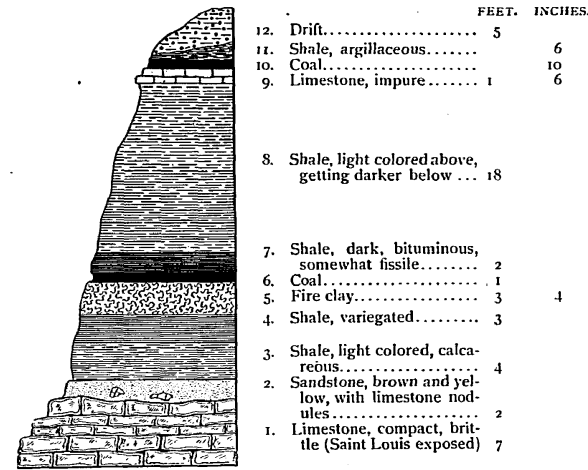

8. Shale, light colored above, getting darker below ... 18

7. Shale, dark, bituminous, somewhat fissile....... 2

6. Coal................. I

5. Fire clay.............. 3

4. Shale, variegated....... 3

3. Shale, light colored, calcareóus................ 4

2. Sandstone, brown and yellow, with limestone nodules.................. 2

I. Limestone, compact, brittle (Saint Louis exposed) 7

Figure 103. Section near old Petit Mline.

worked in it having a thickness of four feet, with two thinner seams beneath. Southeast of Searsboro, in Mahaska county, a couple of miles from the Poweshiek county line, coal mines are also operated in veins three to four feet in thickness.

A number of mines have been opened here and considerable quantities of coal taken out. The nearest of 
these mines to Poweshiek county is the Evans, where the layers seen in connection with the coal are as follows:

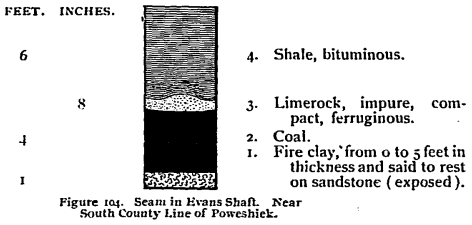

Being located so near the edge of the coal field judicious prospecting in Poweshiek will doubtless reveal the presence of coal in a number of places, and this county may yet be numbered, in the near future, among those yielding commercial supplies of mineral fuel.

\section{MADISON COUNTY.}

The surface rocks of Madison county are largely the limestones and calcareous shales forming the lower portion of the Upper Coal Measures. The drift deposits being thinner than to the westward, outcrops of the stratified rocks are relatively more numerous than in the adjoining regions. In the northeastern part of the county the Lower Coal Measures are exposed over a considerable area.

Although coal has been mined very little in Madison county several workable seams are known to exist near the surface, and, probably, others occur at depths of from 100 to 200 feet. In the northern part of the district, six or seven miles southeast of Earlham, coal is known to outcrop in the valley of North river and some attempts have been made to mine it. On the land formerly owned 
by G. Clarke (Tp. 77 N., R. XXVIII W., Sec. 25, NT. qr.) a seam two feet six inches in thickness occurs. It has not been opened to iny extent, though small quantities of coal are taken out at times for local use. The exposures are near the places where White gave the following section :

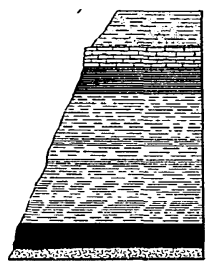

6. Shale, sandy..................... 32

5. Limestone, impure, bluish........... 2

4. Shale, black, bituminous ............ 3

3. Shale, argillaceous, bluish........... 14

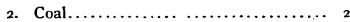

1. Fire clay. $\ldots \ldots \ldots \ldots \ldots \ldots \ldots \ldots \ldots$,

Figure to5- Coal at Clocks Stripping.

Southeast of Earlham.

Coal is also seen in thin bands in other places along North river between the one last mentioned and the east comty line.

On Middle river east of Winterset several small coal seams are exposed above the water level. A mile southeast of Patterson station (Tp. 76 N., R. XXVI W., Sec. 32 , NE. qr., SW. $\frac{1}{4}$ ) the following section is shown :

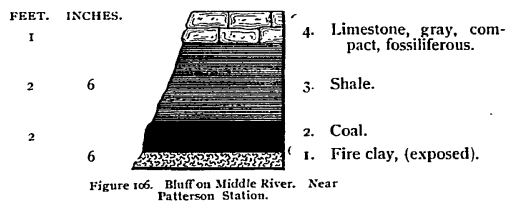

Considerable coal is taken out here for local use during the colder months of the year. Three miles directly east 
of the last mentioned exposure (Sec. 36, SW. qr., SW. $\frac{1}{4}$ ) a five inch seam of coal is exposed at the same horizon. A similar small seam is also shown two miles farther to the southeastward on Clanton creek. There are numerous other outcrops of thin veins in the eastern part of the county and some of them have afforded supplies for the different neighborhoods during the winter.

Coal may, and in all probability does, exist at considerable depths in the northeastern portion of the county and perhaps in most of the district. At $V$ an Meter, one and a half miles north of the county line of Madison, there are two seams of coal three feet in thickness which have been mined extensively at depths of 350 feet below the massive limestone layer, so well exposed near the summit of the bluffs. At Commerce, two miles from the northeast corner of Madison, coal has been mined for years at a depth of 150 feet below the top of the bluffs. There are also openings a few miles east of Madison in Warren county, where the mining industry has been carried on for years.

\section{WARREN COUNTY.}

Coal has been found for many years in this region, but until quite recently it has not been produced in commercial quantities for shipment. Consequently the county has never been ranked among the leading coal counties of the state although having on the north, east and south some of the principal producing areas of the state. The neglect to develop the coal industry in the earlier days of the settlement of the county was probably due in a great measure to the absence in the region of large streams with deeply cut channels. There is probably in the northwestern half of the county at least, as rich a field of coal 
as in any of the neighboring districts. The particular need of deeper prospecting in the coal field is nowhere more apparent than in Warren and would without question lead to the derelopment of extensive mining.

Like neighboring counties, Warren is covered with a tolerably thick deposit of drift which covers most of the exposures. There are no outcrops of Lower Carboniferous strata within the limits of the county, the nearest natural surface exposure of that formation being fully a dozen miles away. The older rocks are therefore probably at a considerable depth below the present surface and in all likelihood borings of 200 feet in depth would fail to reach the basal limestone. The entire county is occupied by Lower Coal Measure strata. Along the western border, however, the beds begin to approach, in lithological character, the Upper Coal Measures. The best natural sections in the region are along the valley of the Des Moines river in the northeastern part. The strata are tolerably level and regular, though a low anticlinal fold has its crest just east of Ford. Connected sections along the three principal streams of the county also indicate that the strata are all very even.

North River Valley.-In ascending North river from the mouth, the first section met with is just north of Carlisle, a short distance above the railroad bridge of the C., R. I. \& P. railroad. Here sandstones and sandy shales rise on the south side of the stream to the height of fifty feet or more. These arenaceous beds immediately overlie important coal horizons which are well exposed a few miles to the eastward. Three miles west of Carlisle is the Lumsdon mine (Tp. 77 N., R. XXIV W., Sec. 7, SE. qr., SW. $\frac{1}{4}$ ). The coal worked lies five or six feet below the level of the small stream on which the mine is located. 
The coal bed is very regular; with no faults or rolls. 'The section shows :

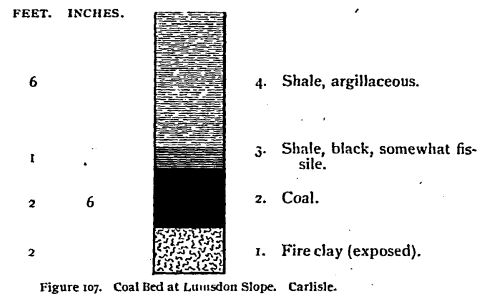

The strata dip to the southeast. The top of the seam is said to be affected by the weather much less easily than the bottom portion. This is also true of other mines in the vicinity. The coal is mined on what is called the "semi-long-wall" plan. A couple of miles above the last named point, just above the wagon bridge over North river on the Indianola and Des Moines road, the existence of coal has been reported. Two and a half miles north of Spring Hill, in the central part of Greenfield township, a three foot vein of coal was formerly worked by several small country banks. At the present time two openings are in operation here (Tp. 77 N., R. XXIV W., Sec. 21, SW. qr.). In the Fourst the seam is twenty-six to thirty inches in thickness. It lies only a few feet above low water level in the river. This coal crops out in several places in a ravine just south of the mine. It is also exposed near the river, about a mile to the west, and is found some little distance beyond in the bed of the stream where it has been quarried for local use. A few rods west of Fourst opening is the Ferry and Graves mine, 
where the seam is somewhat thicker than at the first mentioned place. These two mines furnish most of the coal used in the neighborhood and for some distance to the southward. Five miles farther up the river (Tp. $77 \mathrm{~N}$., R. XXV W., Sec. 3t, NE. qr.) is the Chiles shaft, which is about forty feet deep. The coal is said to be three feet in thickness. A mile from the west county line in the river there are several outcrops showing coal three feet six inches in vertical measurement. West of Spring Hill a couple of miles some stripping has been done in the bed of a ravine for a thin seam of coal. Evidence of former strippings in this vein are found about a quarter of a mile to the northeast in a tributary ravine.

Middle River Valley.-Just west of the county line, in Madison, near Bevington station, a thin seam of coal is exposed near the top of the bluff, but it is probably not thick enough for profitable working. Near Spring Hill, seven miles east of the west county line of Warren, there are two thin seams of coal above the water level in the the river. The lower of these two veins is thirteen inches in thickness and dips to the southeastward. South of Spring Hill is the Earle shaft, 126 feet in depth (Tp. 76 N., R. XXIV W., Sec. 8, NE. qr., NE. $\left.\frac{1}{4}\right)$. The seam worked is three feet ten inches in thickness, and dips to the southeast. East of town a couple of miles, at Glascock Mills, the vein of coal is at the water level, and is from fourteen. to sixteen inches in thickness. Still farther to the southeastward in section 3, (same township and rangè) the coal is mined at the Bemis drift. A seam of coal is also exposed three miles northwest of Indianola, on both sides of the wagon road, near a small ravine.

The chief mines in the comty affording coal in commercial quantities are located in the neighborhood of 
Summerset. A few years ago there were three companies mining coal at this place. They were operating in the so-called "third" vein which is locally known as the Lumsdon seam. The average thickness of the bed is abont four feet. It is reached by shafts varying from sixty to a hundred feet in depth. The mines working this seam at present are the Cassidy (Tp. 77 N., R. XXIII

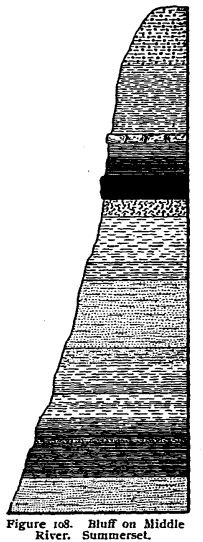

FEET. INCHES.

16. Drift, yellow clay, soil....... 5

15. Shale, gray, fissile.......... 6

I4. Limestone, blue, weathering yellow or brown, with few fossils..

13. Shale, sandy............... I

12. Shale, variegated and bituminous I

I1. Coal, rather impure and slaty... I

10. Fire clay.$\ldots \ldots \ldots \ldots \ldots \ldots \ldots$.

9. Shale, gray, with crystals of gypsum, grading into next above.. 4

8. Shale, sandy, yellow, containing gypsum................... I

7. Sandstone, gray, thin bedded... 6

6. Shale, gray, sandy in upper portion...................... 4

5. Shale, red, gray and blue...... 4

4. Shale, sandy, bituminous ...... I

3. Shale, hard, sandy............ 3

2. Shale, dark blue, argillaceous... 3

i. Sandstone, yellow, thin bedded (exposed to bed of the river).. 3

W., Sec. 31, NW. qr., NE. $\frac{1}{4}$ ), and the Frisbee, the latter being located about a quarter of a mile northeast of the railroad station, on the south side of Middle river. The Caldwell mine is also in the same neighborhood. Prospecting recently carried on south of town indicates that the "third" vein varies considerably in thickness. 
At and near the station of Summerset two thin seams of conl are exposed in the bluffs. They are eighteen and

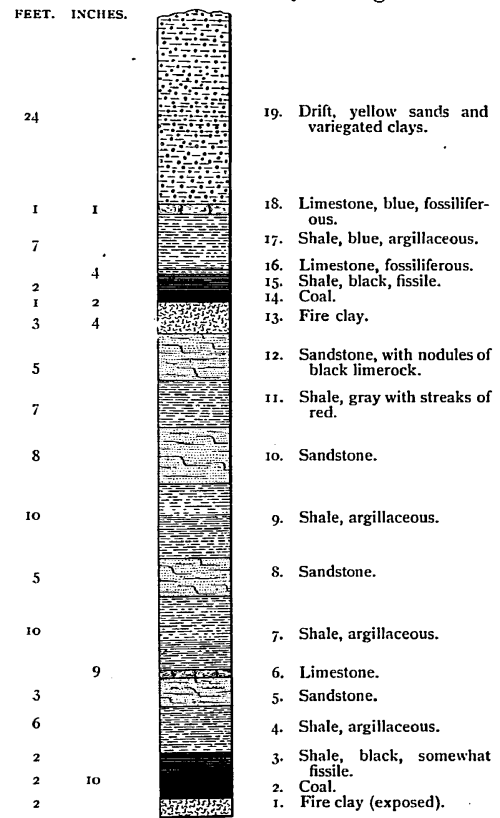

Figure 109. Section of Shaft at Bennum Mine. Summerset.

sixteen inches in thickness respectively, and the upper and thinner of the two has been mined by means of drifts 
at several places in the neighboring hillsides. One of the veins is exhibited on the river as shown in figure 108 .

A couple of miles directly east of Summerset at the Bennum mine ( Tp. 77 N., R. XXIII W., Sec. 33, NW. qr., $N \cdot W^{r}$. 1) the conl is nearly three feet in thickness. To the north is the Jones opening, one of the oldest in the vicinity. At both of these pits the long wall plan of mining is adopted. A section of the shaft of the former is shown in the preceding figure 109 .

Toward the mouth of Middle river little systematic mining has been done, though there are a number of small drifts observed at various places. Directly sonth of Clarkson station in the bed of the river is a fifteen foot bed of bituminous shale. It rests upon a thick layer of clay ironstone which is sometimes exposed at low water. There is, probably, coal immediately underneath. The bituminous shale is overlain by a heavy bed of sandstone, the same layer which is exposed to the westward near Carlisle and a couple of miles to the east at Ford.

Ford was formerly the most important mining district in the county and large amounts of coal were shipped over the C., B. \& Q. railroad. The principal mine worked was the Howell, which was a drift and which operated in a vein three and one-half feet in thickness. This mine has recently been reopened and arrangements are being made for extensive mining. This coal is exposed at the foot of a high bluff and is overlain by a thick stratum of massive sandstone. The strata rise rather rapidly east of the station and within a mile and a half the coal seam has risen thirty or forty feet and at the same time has thinned out to a very few inches. This is shown in the Ford bluff : 


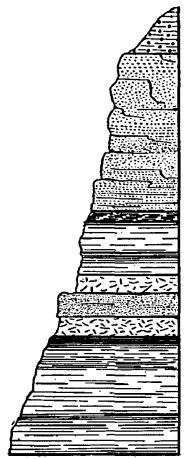

9. Drift and loess

FEET. 1NCHES. 10

8. Sandstone, yellow, soft, heavily: bedded above, thinly bedded below, with much clay....... 35

7. Shale, dark, highly bituminous in places, with hard concretionary layers. ...................

6. Fire clay, with sigillarid roots....

5. Shale, drab, somewhat sandy above. ................... 12

4. Clay, white.................... 3

3. Sandstone, friable, buff, heavily bedded.................... 4

2. Clay, white............... 4

I. Shale, sandy and clayey (exposed to water Jevel $). \ldots \ldots \ldots \ldots \ldots .25$

Figure 110. Bluff on Des sroines River. East of Ford.

South Rirer Valley.-At the present time no coal is known to be mined in commercial quantities in the southwestern portion of Warren. Five miles southwest of Indianola, on the river, a bed of coal one and one-half to two and one-half feet in thickness is known to exist. It was formerly worked to a considerable extent for local use at an opening called the Randolph mine. Here the exposure gives:

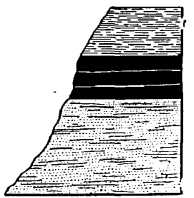

3. Shale, yellow, arenaceous (ex-

FEET. INCHES.

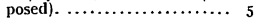

2. Coal, divided by thin clay partings into three benches............ 4

I. Sandstone, blue and yellow, soft, shaly below (exposed )........ no

Figure In. Tripartite Seam at Randolph Jine.

Five miles southwest of Indianola. 
The Demory mine (Tp. 75 N., R. XXIV W., Sec. 9) is a shaft twenty-six feet deep, but is not now in operation. Three miles to the east and about the same distance south of Indianola in the bluff's, is located the Helm mine, where the seam is about two feet in thickness. Coal has also been mined to the eastward on Otter creek. Four miles directly east of Indianola are also located mines near Ackworth station. Five or six miles farther down the stream another vein has been opened and some coal taken out for local use. Between this place and the mouth of the river are other exposures, showing coal, but no mining is known to be carried on at present.

Lacona District.-In the south-central part of the county, along Otter creek, coal is exposed at a number of places. The seam is rather thin, ranging only from twelve to twenty-two inches. West of Liberty Center the vein, on account of a slight southerly dip, is only a few feet above the water level in the creek. A couple of miles farther down the stream are other exposures in which coal has been somewhat irregularly developed. Five miles below and a short distance west of Milo mining has been carried on to some extent. The Bales mine (Tp. 75 N., R. XXIII W., Sec. 26, NW. qr., NW. $\frac{1}{4}$ ) is located two miles southeast of Milo station. A short distance to the northwest, on the creek, exposures of sandstone and shale are shown but no coal erops out in connection with these strata. A mile directly north of the Bales is the Mitchell mine (Tp. 75 N., R. XXIII W., Sec. 23, NW. qr., SW. $\frac{1}{4}$ ). The coal varies from sixteen to twenty inches in thickness and dips north and northwest about two and one-half feet in a hundred. A few slight faults 
have been encountered, though the throw in no case observed is over six inches. The beds exhibit:

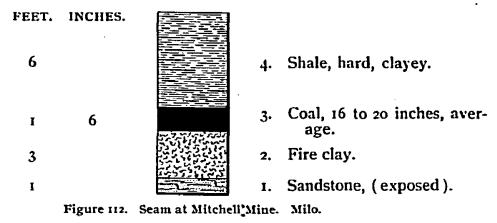

On the same quarter section are located the Morgan and the Connors mines, while a mile. to the eastward is the Brown. The coal here is eighteen inches thick. A mile south of the latter and about the same distance southwest of Milo is the Richmond mine.

Southeast of the town a distance of about three miles ( $\mathrm{T} p$. 75 N., R. XXII W., Sec. 28, SE. qr., SW. $\frac{1}{4}$ ) is the Heinan mine. Near by are other local pits, the Notherhead,

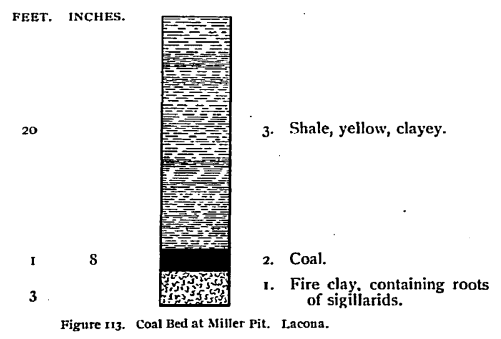

Sneider, and Alexander. Coal has been mined in this vicinity for many years. Among the other openings in 
the neighborhood are the old Dunkin and the Hudson, long since deserted. Both worked in about two feet of coal.

In the valley of Whitebreast creek coal has been mined continuously for thirty years or more. Half a mile southenst of Lacona, on Cotton creek, is the Miller slope (Tp. 74 N., R. XXII W., Sec. 28, SW. qr., NE. $\frac{1}{1}$ ). The coal is of good quality in a seam from sixteen to twentytwo inches in thickness. A portion of the strata visible is indicated in figure 113.

In the immediate vicinity are several openings which were formerly operated for local use. Three-fourths of a mile farther up the creek are several other country banks which are worked only during the winter. Directly sonth of Lacona the coal seam crops out in the bank of the stream, with this section :

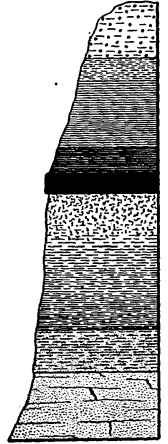

Figure 114. Bluff on Whitebreast Creek. Itacona.
FEET. INCHES.

8. Drift, yellow clay, and soil....... 5

7. Shale, gray, clayey, sandy in the lower part................... 2

6. Shale, blue, fissile, argillaceous.... 6

5. Shale, bituminous, clayey, with gypsum crystals................ 2

4. Coal ................ I

3. Fire clay and light colored shale... 12

2. Shale, soft, sandy, with calcareous concretions $\ldots \ldots \ldots \ldots \ldots \ldots \ldots, 3$

I. Sandstone, massive, compact (exposed $) . . \ldots \ldots \ldots \ldots \ldots \ldots \ldots \ldots, 6$ 
It is also shown at short intervals for several miles down the creek to the east county line. A mile and a half directly southeast of the station just mentioned, on the east side of the creek (Tp. $7+\mathrm{N}$., R. XXII, W., Sec. 26, SW. qr., SW. $\frac{1}{4}$ ), are the Odell and the Fogel banks. The coal mined at this place, and also farther eastward, is about eighteen inches in thickness. Three shafts have been opened in the vicinity. Considerable coal is also removed for local use by stripping along the line of outcrop. A half a mile farther down the creek are the Howe and the Hickman mines besides several smaller banks. In the Hickman mine the coal is from two to four feet in thickness with a good shale roof. The layers are:

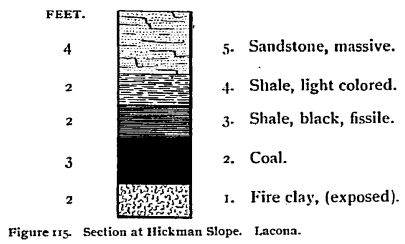

Besides the openings mentioned there are other exposures in the various streams east and northeast of Milo. Thicker seams outcrop farther down the creek and at a lower horizon in Marion county, indicating the presence of workable coal below the thin vein now mined in the southeastern corner of Warren.

\section{MARION COUNTY.}

Marion county for a number of years has been one of the leading coal producing districts of the state. At present it contains many mines which are in operation for 
the greater part of the year; besides a large number of country banks. The county is almost entirely occupied by Coal Measure strata. In the southeastern part the Lower Carboniferous limestone outcrops in a number of places. There are at least half a dozen well defined coal seams in the county. These are nearly all well exposed in the bluffs of the Des Moines river. Other veins, though not represented along the chief water course, probably exist in other parts of the district. In the neighborhood of the southwestern corner the mining of coal has assumed considerable importance just beyond the boundary line in Warren county. The coal,beds of Marion are among the most extensive in central Iowa.

The eastern third of the county is underlain, at no very great depth, by the Saint Louis limestone - the uppermost member of the Lower Carboniferous in Iowa. It forms the floor of the Coal Measures over a greater part of the Iowa coal field. It is exposed in the bed of the Des Moines river for a distance of eight or nine miles from the eastern border of the county to the immediate vicinity of Coalport, four miles southwest of Pella. A small area of the same rock is exposed at low water level six miles farther up the stream near the mouth of Teeter creek, below Redrock. Here the limestone rises in a low anticlinal fold to a height of about fifteen feet above low water level. This is the last outcrop of Lower Carboniferous rocks noticed in ascending the Des Moines river in central Iowa until Fort Dodge is reached. The Saint Louis limestone is also exposed in the bed of English creek as far as Flagler, five miles above its mouth. It also forms steep bluffs thirty to fifty feet high along Cedar creek, extending probably to the southern county line. The limestone also comes to the surface in a number of places 
in the immediate vicinity of Pella. The exposures of Saint Lonis in Marion county show tolerably well its uneven upper surface on which the coal bearing rocks have been laid down. If the latter deposits were entirely removed from the Saint Louis beds the surface relief would probably be not very unlike existing topography. There would be hills and valleys as extensive as those now existing. There is abundant evidence to show that during the closing epoch of the Lower Carboniferous the Saint Louis rocks actually did form a land surface which was subjected to .erosion just as it would be to-day. The extent of this denudation has not been accurately made out in all parts of the region, but carefully made measurements along the Des Moines river indicate that in some places channels have been eut to the depth of fully 100 feet. Between the outcrop of the Saint Louis limestone a couple of miles below Redrock and the exposures at Harvey ten miles to the southeastward no less than seventy-five feet of Coal Measure deposits are known to exist between two horizons where the Saint Louis crops out, showing that after the old Lower Carboniferous hills at Harvey were covered by Coal Measure sediments it required a deposition of between seventy-five and a hundred feet more before the prominence below Redrock was completely submerged.

The greater part of the strata exposed in Marion county above the Saint Louis limestone is comparatively soft and under the influences of the weather pass into incoherent materials upon which vegetation rapidly springs up and hides from view the stratified beds. There are, nevertheless, a few beds which are quite indurated and form marked topographical features. One of the most conspicuous of them is a thick bed which has been 
called the Redrock sandstone. It is well exposed in the river bluffs from the vicinity of Dunreath down the river to Harvey. It probably extends westward and southward bey ond Knoxville, at which point it is some distance below the surfuce. Perhaps it is the same stratum which is exposed in the neighborhood of Tracy, extending along the Des Moines river into Mahaska county to the locality known as the "Bluff"s" or Raven cliff. The sandstone has a maximum thickness of not less than $\mathbf{1 5 0}$ feet. At Redrock bluff and Elk cliff, two miles below, the sandstone rises in perpendicular walls to a height of more than 100 feet. For several miles the Des Moines river flows through a comparatively deep gorge. The bright red color of the stone at Redrock attracted popular attention long ago, the village and township taking their names from it. Immediately below the sandstone is a four-foot vein of coal which has been worked at a number of points. In some places the coal of this seam is not of very good quality, but above the mouth of Whitebreast creek it could probably be mined with profit, as it appears to become better in quality and greater in thickness as it passes northwestward. At least two other seams occur below the vein just mentioned. Both are exposed in the river bluffs at Coalport, where they are from twelve to fifteen feet apart. The lower seam is two to three feet in thickness; the upper five to seven. The details of the geological section of this vein are given in connection with the remarks on the mines at Coalport. The upper vein forms a rather conspicuous black band, extending for several miles along the river, near the top of an almost perpendicular bluff, with a heavy talus at the base, and occurring for some distance above and below Coalport. Three or four miles below Coalport, and from one-half to three-quarters 
of a mile below the Pella and Knoxville wagon bridge crossing the Des Moines river, the coal seam appear's a short distance below the great sandstone stratum already referred to. At the place just mentioned are numerous remains of large, finely marked lepidodendrids, sigillarids, calamites and other types of coal plants in an unusually fine state of preservation. Large slabs from one to three feet wide and several feet long; together with great numbers of smaller fragments of these plant remains lie in the utmost profusion in the talus slope of the river bluffs.

Between the Lower Carboniferous limestone and the lower surface of the great Redrock formation which extends so widely over this region, there are at least seventy-five feet of shales intervening. As has just been said there are now known to be three extensive coal seams inclosed by the shales, and it is quite likely that there are still others of commercial importance.

The upper surface of the Redrock sandstone shows abundant evidence of having been a great land surface, at one time during the Carboniferous, exposed to the denuding action of rumning water. The upper limit of the great sandstone is shown to the best advantage in the Redrock quarry, about three-fourths of a mile above the village of the same name. At this place the full thickness of the sandstone is not represented, as part of it is beneath the water level of the Des Moines river. The upper surface is deeply gorged and channelled, and paved everywhere with rounded waterworn boulder's and pebbles, derived from the sandstone itself. A gray fire clay covers this pavement and upon it rests a conl bed having a thickness of six feet centrally, but rapidly thimning out laterally in both directions to a very unimportant, scarcely recognizable bituminous seam. Northward, or at right angles to 
the face of the section, the coal is thicker. Superimposed upon the coal are drab and ash colored, clayey shales, having an exposed thickness of thirty feet, but which are manifestly more extensive. From a consideration of this section, then, it is clear that before the superimposing coal vein was formed the vast sandstone had been raised above the surface of the waters, consolidated, and was then subjected to considerable denudation. In a small gorge or ravine excavated in the sandstone the Carbonaceous material was deposited as the land was again being: submerged. Immediately to the north the corrasion was much more extensive, as is shown by the rapid inclination of the axis of the gorge in that direction; so that the section is actually across a tributary ravine opening into a large basin, in which the coal is now mined in great quantities. The inference is then that the abrupt disappearance of the great bed of sandstone in the short distance of half a mile above the quarry, where it has an exposure of more than one hundred feet, is not due wholly to the dip of the stratum, but that it is the result of great erosion in that direction, previous to the deposition of the shales and clays; and that the massive sandstone really formed a bare hill of considerable height against which the subsequent deposits were laid, when the conditions for such a change occurred. A short distance above the quarry and about half a mile below Dunreath, at the mouth of Calhoun creek, the Redrock sandstone abruptly disappears and the bluff's on the opposite side of the creek are made up entirely of shales. The absence of the sandstone above water level is not due entirely to dipping, which is really imperceptible here; but chiefly to vigorous subaerial erosion during Coal Measure times. 
In the immediate vicinity of Dunreath there are two or three rather well defined coal seams, one of which has been quite extensively operated for a number of years. Workable coal seams are exposed in a number of places along the river between Dumreath and the northwest corner of the comty: At Bemnington, near a switch on the Wabash railroad called Morgan Valley, a coal vein is exposed a few feet above the river level. It is the same bed which appears on the opposite side of the stream above Swan, at Ford and on Middle river at Clarkson.

In the southwestern part of the county, along Whitebreast creek, there are several coal seams which ontcrop at various points. The best known of these is called sometimes the Lacona coal, from a village of the same name a few miles over the line in Warren county. It is exposed at intervals along the banks of the stream and has been mined at a number of places.

On English and Cedar creeks other veins are exposed, one at Marysville measuring in places eleven feet in thickness.

Marion county has tolerably good railroad facilities, three lines, the C., R. I. \& P., the Wabash and the C., B. \& Q. entering the district. A railroad in the south and western part of the county would doubtless open up large fields of coal.

As already suggested the best natural exposures of Coal Measure strata are along the Des Moines river. Beginning in the northwestern corner of the county, coal outcrops are noticeable along the Wabash railroad and along the river for a distance of a couple of miles. Two coal seams are visible above the railroad track. The upper is about four feet in thickness, the lower about one foot. The seams are separated by ten feet of drab clay shales. 


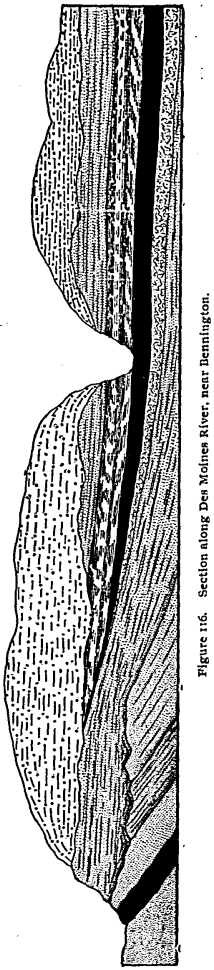

The upper one is overlain by a heavily bedded, buff sandstone, which is the same as that exposed for some distance on both sides of the river and which overlies the coal seam now mined at Ford, in Warren county, a few miles west of the Marion county line. At a distance of about two miles from the western county line, in a ravine opening northward, the upper coal seam has been worked by means of a slope, the mouth of which is about half a mile north of the railroad and a few feet above the creek bed. At this place the coal dips westward, about six feet in a hundred.

On the opposite side of the creek, about thirty yards from the mouth of the slope, a shaft has been sunk by the Morgan Valley Coal Company to a depth of forty feet. This seam is four feet in thickness. But one coal bed occurs at the shaft, though it is said that two seams are present a short distance up the valley. The roof of the coal is a rather compact sandrock, and shows a thickness in the shaft of eighteen feet. It is doubtless much thicker than it appears in the valley of the creek, for here it has been eroded, clays filling part of the depressions. 
A hundred yards east of the Morgan Valley shaft, the rocks are well exposed along the Des Moines river. (See figure 116.) At the west end of the exposure in a small ravine there is seen a two foot vein of coal inclosed in the sandstone. All the beds are inclined at a very considerable angle. The elevation of the different layers is shown in the accompanying section. A few rods farther down the stream a coal seam is exposed for more than a quarter of a mile just above the water level. It is underlain by several feet of fire clay which rests upon shaly sandstone. The coal seam is overlain by six feet of dark bituminous shales, part of which become coaly downward. The beds dip very perceptibly eastward, passing below the water level at the east end of the section.

Continuing down the river along the railroad, indications of coal are seen in the hills at a number of points. In several places drifts have been made. Two miles beyond Percy station the strata gradually rise. In the steep bluff's along the railroad track coal is noticed at several elevations. At Dunreath mining has been carried on quite extensively, though with one exception the mines have been abandoned. Half a mile east of Dunreath the Black Diamond slope has been opened on the lands of the Redlock Mining Company. The coal vein is not very regular, but in places has a maximum thickness of seven feet. The coal is brought up the slope and hauled several hundred yards to the railroad, where it is loaded for shipment. A short distance south of Dunreath, on the river bank, there is a long exposure of the rocks in which two coal seams are shown, one of which is five feet in thickness. This is the vein which has been extensively mined in the slope at Dumreath station. A three-foot vein of cannel coal is said to exist at this point, specimens of 
which show it to be of very good quality. 'The vertical section :

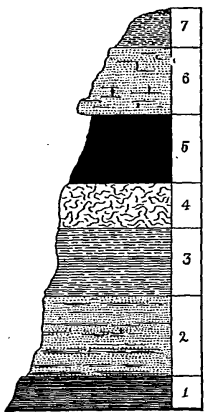

Shale, dark colored, poorly exposed ........ FEET 3

Sandstone, heavily bedded, containing many coal plants, calamites, etc............... 6

Coal. $\ldots \ldots \ldots \ldots \ldots \ldots \ldots \ldots \ldots \ldots \ldots, 6$

Fire clay $\ldots \ldots \ldots \ldots \ldots \ldots \ldots \ldots \ldots \ldots \ldots, 4$

Shale, dark, with thin sandy layers........ 6

Sandstone, shaly, Jarge lens shaped septarial masses at the bottom ............... 7

Shale, black, bituminous, coaly below, ( exposed to water level ).................. 3

Figure 117. Bluff, South of Duureath.

On the river a mile southeast of Dunreath the Redrock quarry is situated. Here a six foot vein of coal overlain by some thirty feet of shale, rests directly upon the sandstone. It has been mined but at present is not being worked. This bed of coal was well exposed a few years ago when the quarry was in full operation. At this time the quarry face was immediately beneath the vein, and this and the overlying shales were freshly cut every few months in order to get at the rock below. Smaller drifts are found in the hills for several miles below this place. Opposite the town of Redrock the high cliff affords : 


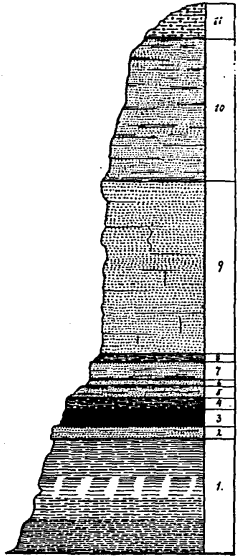

11. Drift

FEET. IXCHES.

ro. Sandstone, yellow; clayey.. 25

9. Sandstone, heavily bedded, buff................. 35

8. Shale, bituminous, coaly... I 6

-7. Sandstone, soft, buff....... pact and fine grained....

5. Sandstone, soft, white.... 2

4. Shale, bituminous, coaly below ............... I

3. Coal, somewhat impure... 4

2. Sandstone, fine, massive, white, with lepidodendrid rootlets ...............

1. Shale, light colored, (exposed $) \ldots \ldots \ldots \ldots \ldots \ldots 20$

Figure t18. Cliff, Opposite Redrock.

Two miles east of Fifield station, and one mile north of Coalport, the following section is seen in a railroad cutting near the river :

FEFT.

7. Drift......................... 5

6. Sandstone, shaly, with carbonaceous seam at base... 10

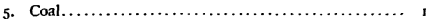

4. Fire clay......................... I

3. Shale, sandy, irregularly bedded............. 4

2. Sandstone, buff, massive $\ldots \ldots \ldots \ldots \ldots \ldots \ldots \ldots, 6$

1. Shale, light colored, argillaceous............. 8 


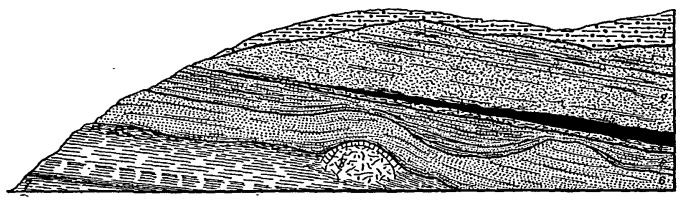

Figure 119. Railroad Cutting. North of Coalport.

The coal dips and thickens to the east. It is overlain by shaly sandstone which often has thin coal seams from a quarter of an inch to two or three inches in thickness in the bottom portion. "Coal and thin bituminous shales are exposed in the creek about a mile east of the last section. A short distance below, the Saint Louis limestone appears above the river level and soon occupies forty or fifty feet of the hill. Of course, all coal found along the river from this point southeastward to the county line must be looked for above the limestone.

North of the Des Moines river, in Marion county, a number of small mines are located along the creeks flowing into that stream. Two miles and a half directly south of Monroe, in the valley of a small tributary of Brush creek (Tp. 77 N., R. XX W., Sec. 12, SE. (11., SW. $\frac{1}{4}$ ) several country banks have been operated; while along the creek itself at several places coal outcrops in the banks.

A mile sonthwest of Otley station the Crawford and Miller mine has been opened (Tp. 77 N., R. XIX W., Sec. 28, NE. qr.). The coal is from five and one-half to seven feet in thickness. The seam is somewhat undulatory, often falling or rising as much as six feet in a hundred. Abont half of the amount of coal mined is nsed 
locally, the other half being shipped. Several other comtry banks are located in the immediate vicinity.

$A$ short distance to the sontheastward and about two miles from Pella is the Markham mine. The coal averages four feet, four inches in thickness. The bed has a con-

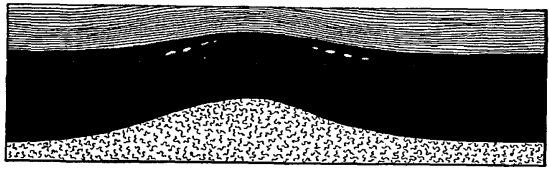

Figure 120. "Rise" in Sarkham Mine. Pella.

siderable extent and has been opened at several other points, though only one mine is at present in active operation. Here the section shows:

FEET.

3. Shale, gray, forming good roof (exposed) ......... 2

2. Coal, numerous concretions in the upper part of the seam, more frequent on top of the rolls.......... +

I. Fire clay (exposed ) $\ldots \ldots \ldots \ldots \ldots \ldots \ldots \ldots \ldots \ldots$, ,

Three miles south of Pella, John Smith, W. Franklin, and Louis Woodyard have opened country mines. The coal is from four to six feet in thickness and of fairly good quality. Several other mines were formerly operated in the immediate neighborhood but are now abandoned. A mile and a half farther southward coal has been mined for local use. The seam is very near the base of the Coal Measures, as the Lower Carboniferous limestone crops out in the river bluft's but a short distance away.

On the south side of the Des Moines river, within a distance of four or five miles of the stream, numerous indications of coal are noticeable. 
At Swan coal mining has been carried on quite exten- sively, several slopes having been driven into the hillsides and a number of shafts sunk. There are three veins of coal ; the first is about twenty-five feet below the level of the railroad track and is a little less than three feet in thickness; the second, which is about fifteen feet lower, is three and one-half feet in thickness; the third is thirty feet below the second, and is four to six feet thick. The Kennedy Coal Company has two shafts not far from the station at Swan. They are about eighty feet deep. Three veins of coal were passed through in sinking the openings. In No. 1, which is just west of the depot, several small rolls have been encountered, but they are not of a serious nature. A short distance farther west the Black Swan Coal Company has recently put down a shaft to the depth of seventy-five feet, reaching the third seam of coal, which is five and one-half feet in thickness. This is a new mine with extensive top works and is reached by a switch from the C., B. \& Q. railroad. Arrangements have been made to handle and ship a considerable output. In former years several other mines were opened directly west of the present shaft of the Black Swan, but these have worked out all their available territory. East of Swan, near the Kennedy No. 2, is the location of the Whitebreast No. 11 (Tp. 77 N., R. XXI W., Sec. 20, $\mathrm{NW}$. qr., $\mathrm{NW}$. $\frac{1}{4}$ ) which is now abandoned. It was a shallow shaft and opened up a seam six feet thick. In working north towards the river the roof became poor, owing to the nearness to the river bed. Several smaller mines have been operated from time to time immediately to the south on Coal creek.

Coal is also exposed in the bluffs of the Des Moines river at several points east of Swan for a distance of three 
or four miles. Southeast of Swan abont three miles there is exposed (Tp. 77 N., R. 21 W., Sec. 33, SE. qr., SW. $\frac{1}{4}$ ) in the small ravine not far from the wagon road a fourteen inch seam of coal. Coal also outcrops in several of the deep ravines a couple of miles east of the latter locality. Four miles west of Redrock, drifts have been made in a number of places in the hillsides near an old channel of

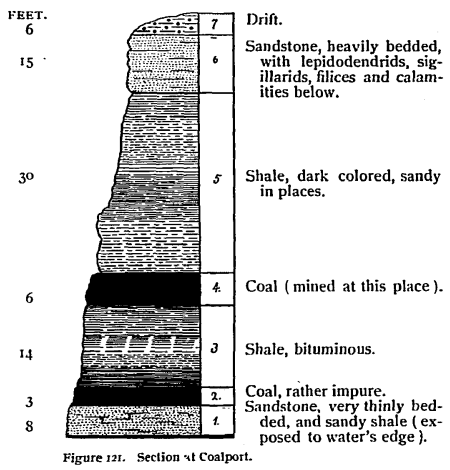

the Des Moines river. About a mile south of Redrock is a four foot vein of coal immediately. underneath the Redrock sandstone and about twenty feet above the water level in the Des Moines river. It is exposed also at several places below this point and in the valley of Teeter creek, and has been opened at all of these places. Near the ferry, at Rouseau post office, the same vein of coal is exposed under the great sandstone. At the mouth of 
Whitebreast creek and for some distance above, dark bituminous shales crop out in the valley sides and at places prospecting for coal has been carried on with some success.

At Coalport, five miles southwest of Pella, on the west side of the river, coal has been mined for more than forty years. There are two veins; one three feet thick, eight feet above low water level in the Des Moines river, and the other vein six feet thick, fifteen feet higher up. The coal is loaded on wagons and hauled to Flagler or Pella for transportation. The section of rocks at this place is shown in the preceding figure 121.

For several miles below Coalport the upper seam is exposed high in the bluffs, forming a conspicuous black

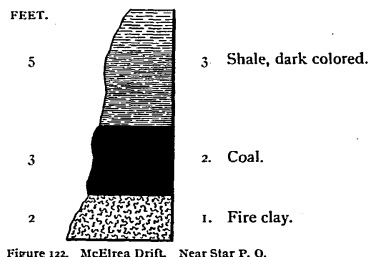

band immediately beneath the sandstone. Drifts have been driven at various places and coal taken out for local use.

In the vicinity of Pleasantville along Coal creek, three miles south of the town, coal has been found in a number of localities.

In the valley of Whitebreast creek coal is found at intervals in the bank throughout its entire length from the southwestern corner of the county to where it empties into the Des Moines river: There are two small mines 
on the creek near Star post oflice, one in Tp. 75 N., R. XXI W., Sec. 24, NE. q1., SE. $\frac{1}{6}$, and the other in Tp. 75 N., R. XX W., Sec. 30, NW. qr., N W. $\frac{1}{1}$. The former is the McElrea drift, a section of which is indicated in figure 122.

The vein is about three feet in thickness and quite regular. The roof is a hard shale, and said to be about sixteen feet in thickness. There is another seam said to be exposed above this one, and which is thought to be the same vein as that mined at Lacona, in Warren county. About two miles north of Dallas village, in a deep ravine opening into the Whitebreast, there are two country banks operating in a three foot vein of coal. Coal is found in the southwestern part of Dallas township near the county line. Six miles southwest of Knoxville, and at short intervals for several miles down the stream there are numerous outcrops of coal. It has been mined in the neighborhood of Donaldson station, three miles northwest of the same town. Near Knoxville are several shafts, the coal being forty to fifty feet from the surface. The section of the bed at Knoxville is shown in the following figure 123 .

A number of openings have been located immediately north of Knoxville (Tp. 75 N., R. XIX W., Sec. 6, SE. qr.) among the older of which the Collins mine was, perhaps, best known. This mine, which at different times was called the Collins, James and Knoxville City mine, was a shaft eighty feet deep and worked in a seam which averaged about four feet in thickness. The vein had a shale roof and was slightly undulatory. The coal seemed to lie in a trough about one-fourth of a mile wide and running from northwest to southeast. Immediately east of it (Tp. 75 N., R. XIX W., Sec. 6, SE. qr., SE. $\frac{1}{2}$ ) considerable coal has been taken out by W. Gamble. He 
has opened three mines altogether, the one now being operated being a shaft forty feet deep. The coal is four feet thick, with a slight southerly dip. In a small ravine just north of town (Tp. 75 N., R. XIX W., Sec. 6, SE. qr., NW. $\frac{1}{4}$ ) two small slopes, the Anderson and the Miller, have been opened. The coal is from two and a half to four feet in thickness, with a dip to the southward of

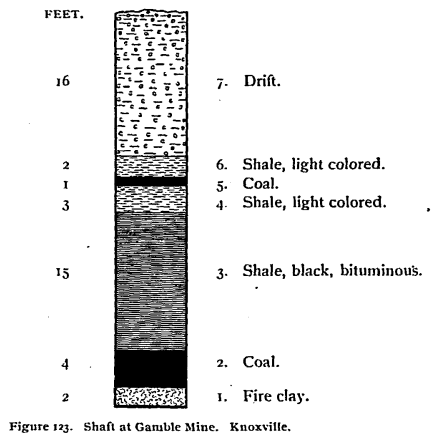

nearly ten feet in a hundred. A number of small slips or faults have been found, but none of a serious character.

In the valley of English creek a large number of shafts and country banks have been operated. In Washington township, in the southern part of the county, several mines have been worked in the vicinity of Gosport. Two miles west of this place, on Long branch, the Lackey drift has recently been opened in a seam three feet in thickness. The bed is somewhat undulatory, but has a general dip towards the southeast. The roof is drab shale and rather 
poor. A mile east of the latter locality, at the mouth of Long branch, the Bingham slope was formerly operated. The coal is apparently the same as at the Lackey mine but is somewhat thicker. Coal crops out in the banks of the stream and its tributaries at short intervals for a distance of eleven or twelve miles. 'Three miles southeast of Knoxville a number of openings have been made; while two miles directly south is the Robinson slope ( $\mathrm{T}$ p. $7 \overline{\mathrm{s}} \mathrm{X}$.. R. XIX W., Sec. 19, SW. qr.. NE. $\left.\frac{1}{4}\right)$. The air shaft is twenty-five feet deep. The coal is five feet in thickness and dips quite perceptibly sonthwestward. Half' a mile directly east is the Buckman drift. 'Two veins of coal, which are separated by about twenty feet of shale, are present. There is probably a third seam below. The second vein is from three and a half to four feet in thickness. Some "horse-backs" have been encountered in the mine, but none canse much trouble. A mile still farther eastward in section 21 of the same township and range is the Martin mine. In sections 15 and 16 respectively are the Griffith and Hayes banks. At the latter place the average thickness of the coal is five and one-half feet. Immediately southeast of Flagler there are a number of coal exposures along the creek.

At Flagler the Saint Louis limestone is exposed southward in the bed of English creek, as well as in a small tributary of a stream running through the town and along which the railroad has been built. Between these two streams, rising to a height of 50 to 100 feet, is a long narrow strip of land which is made up of Coal Measure strata. It consists mainly of two sandstone layers, the lower one of which is a white, shaly sandrock said to have a thickness varying from fifteen to fifty feet; the upper sandbed is usually thicker; it is a massive, soft, 
yellow sandrock closely resembling certain parts of that quarried at Redrock, six miles to the north. Two seams of coal are known, both of which have been worked. The one occurs between the two sandstone beds and the other at the base of the lower. The coal which was first opened in this vicinity belonged to the upper seam; but later the lower bed was discovered and worked. As elsewhere the coal has been found to lie in beds which are quite variable in thickness. In the Whitebreast No. 11, now worked out, the coal formed a lenticular basin which was fourteen feet thick centrally. From this point the bed thinned out in all directions until too thin for profitable working. The Iuka slope is now operated at this place in a vein six feet thick. The coal is somewhat variable in thickness, running from four to six feet and upwards. It has a dip towards the southwest of five to six feet per hundred.

At the Rollins mine near by the following is seen :

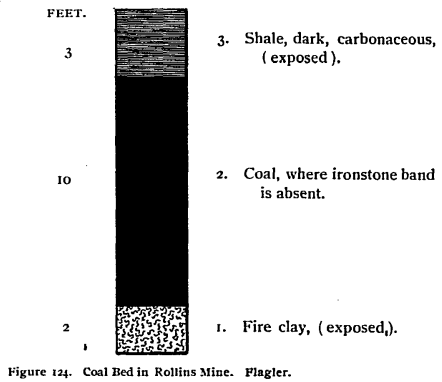


In another place a thick band of elay ironstone comes in, giving :

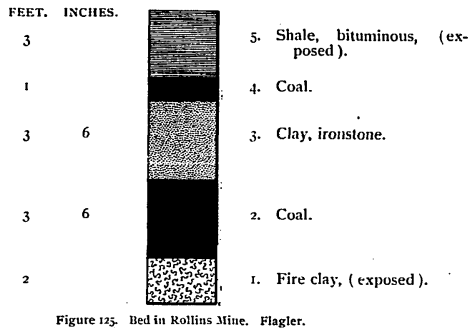

About one mile east of here the Oak Hill Coal Company has a slope working in apparently the same vein.

In the valley of Cedar creek coal is well exposed and a number of mines have been opened. Most of them are four or five miles away from the railroad and hence very little of the product is shipped. A mile and a half southwest of Marysville (Tp. 74 N., R. XVIII 'W., Sec. 31, NE. qr., SW. $\frac{1}{4}$ ) is the Whitelatch slope. A few hundred yards east of this is the Staats opening, in which the coal is from ten to eleven feet in thickness. At this point the bluff shows a section as indicated in figure 126 . The same vein is also exposed along the creek a short distance west of Marysville. South of this place ('in section 32) are the Yenser, the Leivy and the Walters mines, which are operated chiefly for local use. From the Yenser mine, however, coal is sent to Hamilton and loaded on railroad cars. The seam is from four to five feet in thickness. A mile west of Hamilton mines have been opened in the northwest quarter of section 34, among which may 
be mentioned the Davis. The coal from this place is also hauled to the railroad for shipment. Within a distance of a mile north and northwest of Hamilton half a dozen mines have been opened. In the vein at Tracy several small mines have been open for a long time.

The Boudinot slope, in the northwest quarter of section 27 (Tp. 74 N., R. XVIII W.) also sends much of its

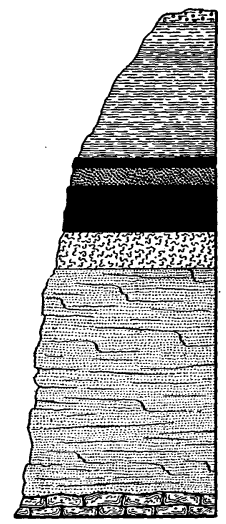

Figure 126. Bluff on Cedar Creck.
8. Soil.....................

7. Clay shale, light colored above, dark below ...................... 30

6. Coal ........................ I

5. Clay ironstone $\ldots \ldots \ldots \ldots \ldots \ldots \ldots, 2$

4. Coal........................ 5

3. Fire clay, white............... 4

2. Shale, hard and gritty, followed by thinly bedded sandstone and sandy shales to the water level........... 5o

1. Limestone, Saint Louis (exposed at low water) $\ldots \ldots \ldots \ldots \ldots \ldots \ldots \ldots$.

output by wagons to the railroad station. This mine is located on Cedar creek; the coal runs from five to seven feet in thickness and is firm, hard and of good quality.

A short distance north of Hamilton, on the C., B. \& Q. railroad, is the Novelty mine, a small shaft. The section at this point is as follows: 
10. Clay, yellow

FEET, INCHES.

7. Shale, gray $\ldots \ldots \ldots \ldots \ldots \ldots \ldots \ldots \ldots \ldots$ so

6. Shale, dark gray, fissile................ I4

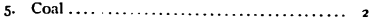

4. Shale, black, fissile.................... 20

3. Coal $\ldots \ldots \ldots \ldots \ldots \ldots \ldots \ldots \ldots \ldots \ldots, \ldots \ldots \ldots$, s

2. Rock ......................... 3

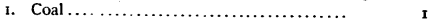

The rock (No. 2) between the two parts of the coalis clay ironstone. It disappears farther westward and the

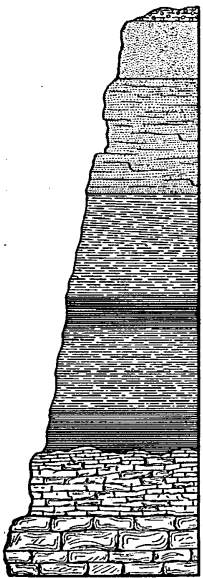

4. Soil

FEET

3. Sandstone, light colored, more or less shaly.

2. Shale, light colored above, bituminous below, resting unconformably upon the next $\ldots \ldots \ldots \ldots \ldots \ldots \ldots \ldots \ldots \ldots \ldots, 35$

I. Limestone, decomposed and weathered above, solid and massive at base, (exposed to water level ) .............. 16

Figure 127. Bluff on Cedar Creek. Showing Coal sieasures Resting on Saint Louis Limestone. Near Bussey. 
two seams run together. Another conl vein is known to exist below that now worked, since a prospect shaft about 500 feet to the westward shows one vein to be five feet in thickness; and beneath this one six feet of black shale and six feet of coal. This intervening shale is in one place nineteen feet thick.

At Bussey the Powers shafts, two in number, operate in a four foot vein of coal. The coal product is hauled on a tramway from the mines (Tp. 74 N., R. XVII W., Sec. $14, \mathrm{NW}$. qr.) to the railway where the tipple is located. The greater part of the coal from this mine is shipped out of the state. On Cedar creek, near Bussey, the Coal Measures are seen resting on the Saint Louis limestone, as shown in figure 127 .

\section{MAHASKA COUNTY.}

From the earliest days of the settlement of the Des Moines valley Mahaska county has ranked among the leading coal producing districts of the region. Owen, in his celebrated exploration of the northwest in the later forties, found coal within the limits of Mahaska, and in a few years announced to the world the existence of rich deposits of mineral fuel in central Iowa. Mining, therefore, early became an important industry in this section of the state. The first localities where important mines were opened were in the immediate vicinity of Oskaloosa on Spring creek, south of that town on the Muchakinock and on the Des Moines river.

Although natural outcrops are numerous in nearly all parts of the county, little has been done until quite recently towards acquiring exact knowledge regarding the geological structure of the district. In the beds of the principal streams traversing the county the Lower 
Carboniferous limestones are well exposed. These calcareous strata, though forming almost continuous belts bordering the streams, are quite irregular, both in areal distribution and vertical extent. Usually the beds rise from a few to thirty or more feet, occasionally dropping below the level of the water courses. Lithologically the formation is a white or ash colored, compact, brittle limerock, rather thinly bedded, and of ten somewhat brecciated. Frequently the upper portion is covered by a few feet of white, highly fossiliferous, marly clay. Both the limestone and the clay belong to the Saint Louis formation, which is even better developed farther southward. - In this part of the state it forms the basement upon which the coal bearing strata rest. As in all other parts of the state in which the rocks of the same age are exposed, the upper surface of the Saint Louis limestone is very uneven, the difference in level of neighboring inequalities being often from fifty to one hundired feet. These peculiarities of the Coal Measure platform have an important bearing upon the structure, distribution, and arrangement of the coal beds. What doubtless is the case over the entire county is disclosed plainly along the different water courses. On the North Skunk, in the eastern part of the county, it is not uncommon to find an exposed ledge of the limestone abruptly replaced by Coal Measure shales and sandstones, while a short distance beyond the limerock again comes up suddenly. It is quite manifest, after a careful consideration of the stratigraphical relations of the two formations, that the sandstone fills old gorges or eroded depressions in the limestone. Similiar outcrops are seen on the South Skunk, in the eastern part of the district, and on the Des Moines river at "The Bluffs" or Raven Cliff, where a massive sandrock forms a bold mural 
escarpment 100 feet in height, extending more than two miles between two old limestone hills.

The country being comparatively free from marked differences of elevation, and the drift not very deep over the greater part of Mahaska, the major part of the strata above the Saint Louis limestone may be regarded as made up of Coal Measure deposits, so that the formation spreads over the entire county with a maximum thickness of perhaps $\mathbf{1 5 0}$ feet. From this extreme limit it varies down to nothing. This variability in the vertical measurement of the Coal Measures is not the result of post-Carboniferous erosion entirely, and the consequent irregularities of the present surface relief; but is due largely to unevenness of the basement upon which the formation rests. Thus Coal Measure strata may exist at lower levels than certain outcrops of Saint Louis limestone and yet everywhere overlie the latter.

The coal seams of Mahaska are disposed in rather large basins. There are several coal horizons in the county, but the exact extent of each has not as yet been made out.

North Skunk Valley.-Although the Lower Carboniferous limestones are exposed in the bed of the river for the greater part of the distance which the stream traverses in the county, coal seams have been opened at short intervals. In the northern part of the county, northeast of New Sharon, along Buck creek, mines have been in operation for a long time and considerable coal removed. The beds are near the surface and are reached by drifts, slopes or shallow shafts. There have been many openings in the district, but few of them have been operated for more than two or three years, as it is more economical to make new entries as the coal is removed from the immediate 
vicinity of the mouth of the mines. In thickness the coal varies from two and one-half to six feet. A good shale roof is usually present. Occasionally small slips are met with, but rarely any serious "troubles." The most northerly mines of the district are the Evans openings ( $\mathrm{T}_{\mathrm{p}}$. 77 N., R. XV W., Sec. 5, SE. qr., SW. $\frac{1}{4}$ ), one of which is within one mile of the Poweshiek county line. The coal is from three to four feet in thickness, with an average of perhaps three and one-half feet. Near by is the Smith mine, which also operates in coal from three to four feet in thickness. Half a mile sonthward are the Williams mines, only one of which is running at the present time. Here the section is:

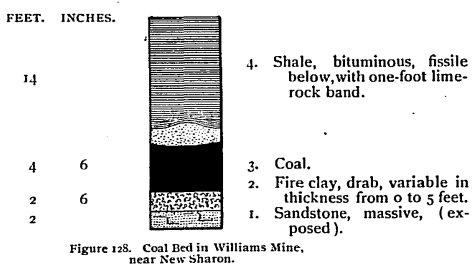

In the southeastern part of the same section are several openings known as the Fisher mines.

Although the Coal Measures are well exposed at short intervals and exist in the bluffs on both sides of the stream from the last mentioned point to the east county. line near its central part, little or no mining is now being done until the eastern margin of the county is reached. On the north side of the river, three miles from Rose Hill station, is located the Columbia mine ( $T$ p. 76 N., $R$. 
XVI.W., Sec. 36, NW. gr., NE. $\left.\frac{1}{4}\right)$. At this place the following section is observed:

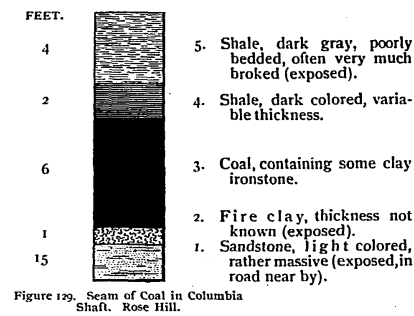

The coal is from five to seven and one-half feet in thickness. Here, as elsewhere in the county to some extent, the coal seam is very undulatory the seam rising and falling at very short intervals and at high angles. The low parts of the vein are very appropriately called "swamps" by the miners, and it is only in these places that the coal can be mined, because of the poor roof over the higher portions, the coal itself remaining unimpaired. In no part of the county, perhaps, is there so great a variation in the charater of the roof. In places there is a sandy rock; at other points a good hard shale; elsewhere a poor roof of soft, blue clay.

South Skunk Valley._Comparatively little mining has been done in the immediate vicinity of the stream. The principal openings are in the neighborhood of Oskaloosa and will be considered in connection with that district: In the nortliwestern part of the county a few country banks have been opened a few miles south of Peoria (Tp. $79 \mathrm{~N}$., R. XVII W., Sec. 12, NW. qr., NE. $\left.\frac{1}{4}\right)$. On the lower 
portion of the river the chief mines are located near Rose Hill. Several mines have been rumning three miles west of the station, but at the present time only one is in active operation, the Carey (Tp. 75 N., R. XIV WV., Sec. 6, NE. q1., NW. $\frac{1}{4}$ ). The seam here worked is from five and one-half to seven and one-half feet in thickness. The coal is near the surface. The roof is a dark shale, good throughout. The coal is mined by cutting out the bottom of the bed. By this method of working the upper coal may be wedged down or by a horizontal blast may be removed in large masses which prevents the formation of very much fine coal and slack. The lower and upper coals separate easily though there is no true parting. They show a slight difference in quality, the upper part of the seam appearing brighter and heavier. A mile to the west is the White bank where coal has been mined for several years. Other country banks are situated in this vicinity and also south of Rose Hill a couple of miles, near White Oak post office.

Oskaloosa District.-Around the county seat of Mahaska centers the leading mining activities of the region; and from this point radiate no less than nine lines of railroad. The mines embraced in this district are those located in the immediate vicinity of the town.

Northeast of town on Spring creek, coal has been mined for a long period of years. The coal crops out in the banks of the creek and has been opened by means of drifts for local use. A number of important shafts have recently been sunk, the leading ones being controlled by the Central Iowa railroad. The most northwesterly mine is the Hoover (Tp. $75 \mathrm{~N}$., R. XV W., Sec. 8, NE. qr., SW. $\left.\frac{1}{4}\right)$. The present shaft is the second put down on a ten-acre tract. The output is chiefly for local use. 
Sontheast of the Hoover a short distance are the Carbonado mines, two in number. There is shown here:

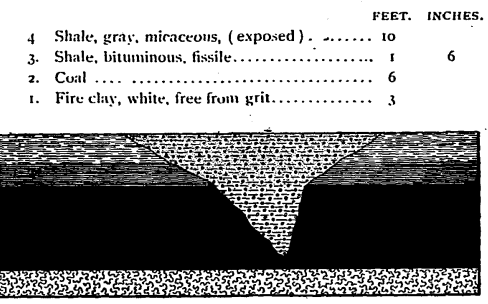

Figure 130. Coal Bed, having Erosive Channel filled with Drif Material. Carbonado Mine. O-kaloosa.

The mines hare been in operation about three years, and nearly 300 acres of coal have mined, but the area worked over is considerable more than this. Much coal yet remains untouched, because of its softness or the weakness of the overlying material which consists largely of clrift. The roof is a bituminous fissile shale containing many coal plants, and is overlain by from ten to forty feet of peculiar gray shale. The shafts of the Carbonado mines are ninety and ninety-four feet deep. The seam is from four and a half to seven feet in thickness, averaging perhaps six feet. It is quite undulatory, so much so that two mules are sometimes required to haul out one mine car from the side entries to the tail rope in the main entry. In parts of the mine a hard bituminous limerock is found near the top of the seam. A troublesome fault has been encountered near the north boundary line of section 8 . This " trouble" is probably a preglacial channel, though the quality of the coal remains unchanged to the sharp line 
dividing it from the drift material, which takes its place. The old channcl has been traced over a quarter of a mile to the northwestward, widening out rapidly in that direction. Within the corporate limits of Oskaloosa (Tp. 75 N., R. XV W., Sec. 18, SE. qr., SW. $\frac{1}{4}$ ), the Economy mine has lately been opened in a five foot seam of coal, lying at a depth of eighty feet. The roof is said to be similiar to that at the Carbonado.

At the works of the Oskaloosa Paving Brick Company a thin seam of coal was formerly mined for use in the plant, but no coal is now taken out. There were several other mines on a branch of Spring creek near the Oskaloosa and spring Hill road, but these are now deserted.

West of Oskaloosa extensive mining has been carried on though many of the openings are now worked ont. Within the city limits is the Long mine (Tp. $75 \mathrm{~N}$., R. XVI W., Sec. 23, NE. qr., NE. $\left.\frac{1}{4}\right)$. The shaft is ninety feet deep, with coal from three and one-half to seven feetin thickness. An eroded channel cutting out the coal has been found about a quarter of a mile northwest of the shaft. The output is shipped over the C., R. I. \& P. and the B. \& N.W. railroads. The Reigel mine is a local opening situated just south of Oskaloosa College. In the same neighborhood there are a number of abandoned mines on the south side of the Rock Island railroad. Among these are the Acme and Standard mines, both of which have been deserted for several years. The mines now in operation in this vicinity are five in number, of which the Oskaloosa No. 1 is the largest. It is situated southwest of the Reigel ('Tp. 75 N., R. XVI W., Sec. 23, SE. qr., NTV. $\frac{1}{1}$ ). The shaft is eighty feet deep, with coal from six to seven feet in thickness. The mines of the Standard Coal Company were situated in the 
southwest quarter of the same section. On the north side of the road near this place is the McFay and Cook slope which has recently been opened. The coal is four feet, four inches in thickness. In the extreme northwestern corner of the same section is located the Guthrie shaft, on the Oskaloosa and Bellefountaine road, half a mile west of the city limits. The shaft is sixty feet deep, with an average of six feet of coal. Three feet of coal are also exposed in a brick yard at this point. The following is the association of strata :

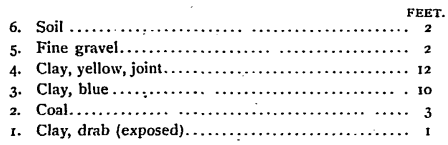

In the exposure the coal shows a marked dip to the southwest, but this is merely a local inclination of the seam. A short distance west of the Guthrie opening is an abandoned mine called the Logue, and in the same vicinity several others. Recently, a short distance west of the Guthrie place, a new slope has been opened in four and one-half feet of coal; and a short distance still farther northward the Andrews mine, which is a shallow shaft working three and one-half to five feet of coal. At this place the seam is about thirty feet above the railroad track and appears to have a general inclination northwestward.

Muchackinock Valley.-This has long been known as one of the most important mining districts of the county. The development of the coal industry along this particular line is probably due largely to the building of the Des Moines Valley railroad along this creek, leaving the Des 
Moines river at the sonthern border of the county. Toward the northern edge of the district extensive mines were formerly in operation near Leighton, but at the present time little coal is taken out in the immediate neighborhood of the station. The openings are nearer Fishville than Leighton, and properly belong to this district. The old Leighton mines are located just northwest of Fishville station (Tp. 75 N., R. XVII TV., Sec. 1, SE. qr., NW. $\frac{1}{4}$ ). The principal one is a shaft thirty feet in depth and is now known as the Davis mine. The coal is

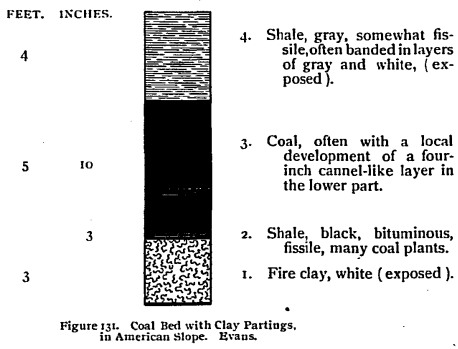

five feet in thickness. The roof of the seam is a hard shale and forms a good covering. In the same vicinity were several drifts known as the Hoover mines. A short distance to the southwest is the Patterson shaft, which is seventy-six feet deep and working four and one-half to five and one-half feet of coal. Near the station is Fishville No. 2 (Tp. 75 N., R. XVII W., Sec. 12, NE. qr., NE. $\frac{1}{4}$ ). It is a shaft fifty feet deep. Fishville No. 1 is a drift now abandoned. 
A mile farther down the creek, and a half a mile west of Evans, is the American mine, one of the largest in the state (Tp. 75 N., R. XVI W., Sec. 18, NW. qr., NW. $\frac{1}{4}$ ). The mine has been in operation for nearly fifteen years, and coal is taken out for more than a mile from the mouth of the slope. Electric haulage is used throughout the mine. There is a double entry, the loaded cars going out one and the empty ones returning through the other. The two entries are separated by a wall of coal. The seam is quite regular and arerages about six feet in thickness. Faults are few, but several rolls occur. The section shown in the mine is indicated in figure 131.

In some places a thin seam of cannel and slaty coal occurs near the middle of the seam. These boney layers

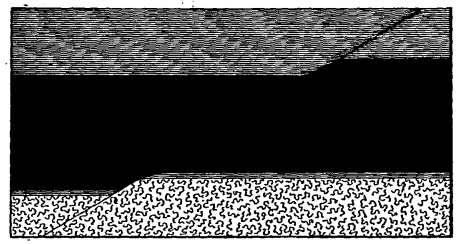

Figure $\mathbf{1 3 2}^{2}$ Fault in American Mine. Erans.

vary from two to six inches in thickness. Ironstone nodules also occur, usually near the top of the seam. In one place these concretionary masses are upwards of twelve feet in length and two feet in thickness. A few small faults have been observed in different parts of the mine, one being represented in the accompanying figure (132). Another slip is shown in the following figure (133), the line of movement passing through an irregular band 
of hard ironstone and showing a change of direction in passing from the softer to the hurder layer. There is an old abandoned shaft near the American mine from which coal was formerly taken out in considerable quantities. A mile and a half directly sonth of Evans is the Hull mine.

In the vicinity of Beacon mining has been carried on quite extensively. North and northwest are a number of abandoned mines. A short distance west of the station is located the Garfield mine, which is a drift. The coal is from four to six and a half feet in thickness with an average of about five feet. In places there is an impure

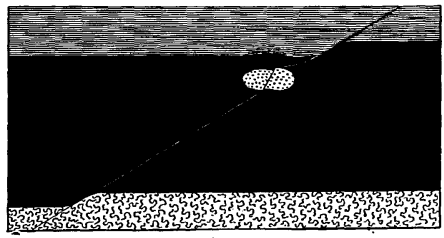

Figure 133- Fault in Ametican Mine, Evans, Line of Slip Passing Through Irregular Ironstone Batid.

limerock from one to three feet in thickness separated from the coal by six inches to one foot of drab shale. At one point the upper portion of the coal is separated from the lower part by several inches of black shale. A short distance to the southwest is the Greene mine, where the coal seam is sometimes seven and one-half feet in thickness. The roof is charged with the remains of coal plants. A fourth of a mile west of the Greene mine is the Oskaloosa No. 2. In the same vicinity is the American mine, which is not in operation yet, and the Mahaska mine, which has been abandoned. South of 
Beacon there are two important mines. The Northwestern or Consolidation No. 8 (Tp. 75 N., R. XVI W., Sec. 34, SW. qr., SW. $\frac{1}{4}$ ) is a shaft 108 feet deep. The Oskaloosa No. 3 is a short distance to the northeast. It is sixty feet deep with coal five and one-half to six feet in thickness, and covered by a dark bituminous limerock.

East of Beacon are a number of abandoned mines which are said to have operated in coal six feet in thickness. Two miles southeast of the station is the Consolidation No. 7 (Tp. 76 N., R. XVI W., Sec. 36, NE. qr., NE. $\frac{1}{4}$ ). It is 150 feet deep. The strata at the bottom of the shaft show :

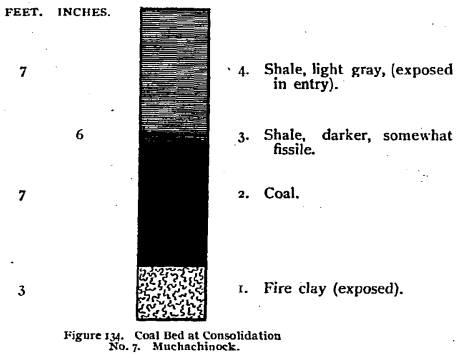

Three-fourths of a mile to the southeastward is the Consolidation No. 6. A short distance beyond is the Smith, a shaft 150 feet deep with coal four and onehalf to seven feet in thickness. The roof is bituminous limestone and is commonly called "hydraulic rock."

West and sonthwest of Given station are a number of deserted mines. The Griffith shaft is a country bank of 
considerable importance. The bluff near the mine shows the following sequence of layers :

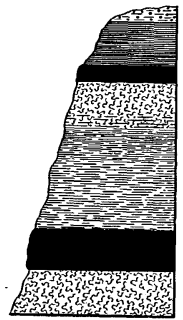

6. Soil ................................... FET

5. Shale, dark gray, somewhat fissile .......... 3

4. Coal $\ldots \ldots \ldots \ldots \ldots \ldots \ldots \ldots \ldots \ldots \ldots$, I

3. Fire clay, and clay shale............. to

2. Coal $\ldots \ldots \ldots \ldots \ldots \ldots \ldots \ldots \ldots \ldots \ldots, 3$

1. Fire clay (exposed $) \ldots \ldots \ldots \ldots \ldots \ldots \ldots, 3$

Figure 135. Bluff at Griffith Drif.

The old Ellis bank was near here and also the Thompson and Eureka mines.

Three miles to the southeastward is an important mine - the Pekay (Tp. 74 N., R. XV W., Sec. 20, NW. qr., NW. $\frac{1}{4}$ ). The coal is from four and one-half to five and one-half feet in thickness. The section is shown by the following :

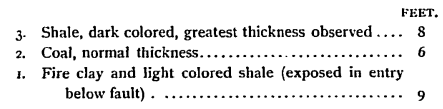

A few hundred feet south of the shaft in the main entry the coal rises and is faulted as shown in the following figure 136 . 


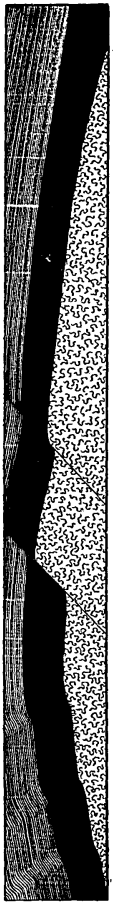

In a distance of twenty-five yards the strata rise nine feet. There is a fault having a throw of about two feet. Five yards farther on there is another drop of five feet. From this point the strata gradually fall, reaching to the level of the track in a distance of forty feet. There are also in this distance three sharp bends or jogs in the coal bed. These are slight, for the coal seam has not been fractured. Mining has also been carried on along Lost creek and in the vicinity of Eddyville, but little operating is being done at the present time at these localities.

In the southeastern corner of the county, at Fremont, is an exposure showing indications of coal. The section is shown in figure 137.

Southwest Mahaska.-Along the Des Moines river coal has been taken out at a number of points. Near the mouth of Cedar creek, half a mile south of Bellefountaine, there is an exposure showing the upper eroded surface of a thick sand formation, which may be the southern extension of the Redrock sandstone. The representation is shown in cut 138.

The measurements represented are about 200 feet for the horizontal and seventy-five feet for the vertical. The 
sandstone is capped by about eight feet of compact, somewhat earthy limestone. Both have been deeply eroded by

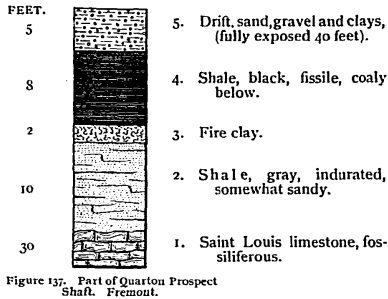

5

8

Io

$3^{\circ}$

5. Drift. sand,gravel and clays, (fully exposed 40 feet).

4. Shale, black, fissile, coaly below.

3. Fire clay.

2. Shal e, gray, indurated, somewhat sandy.

1. Saint Louis limestone, fossiliferous.

Figure 137. Part of Quarton Prospect

Shaft. Fremout.

an ancient water course having a channel in an east and west trend. This channel has been filled with dark clay and shale from twenty to thirty feet in thickness. Then there is a bed of coaly shale, somewhat irregular, and rising rapidly towards the east, where it is four feet in thickness. Towards the west it thins out to about eigh-

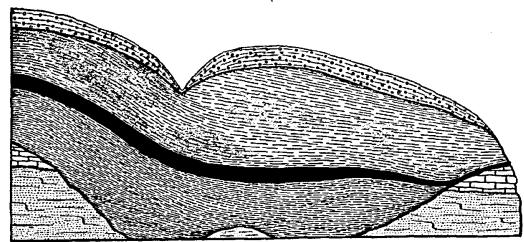

Figure 138. Section at Mouth of Cedar Creek. Below Bellefountaine.

teen inches, rising over the limestone. This coaly layer is covered by thirty to forty feet of argillaceous and sandy 
shale. A short distance south of the section named, which is at the iron bridge over Cedar creek, is the Hollowell mine, and a mile east of the bridge is the Ream. A short distance below the latter is a high cliff known locally as "The Bluffs," which extends for a distance of nearly two miles along an old channel of the Des Moines river. It forms a mural escarpment of massive sandstone seventy-five to 100 feet in height. A few miles down the river, near Ferry post office, coal has been mined for local use in a number of places. Three miles to the southwestward are several openings which are known as the Richardson mines. The principal one is now called the Day opening (Tp. 74 N., R. XVII W., Sec. 15, NW. qr., SW. $\left.\frac{1}{4}\right)$. The section is shown by the following:

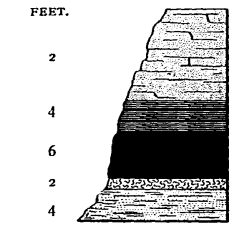

5. Sands tone, massive, somewhat ferruginous, with many coal plants.

4. Shale, black, carbonaceous, with numerous coaly layers.

3. Coal, rather slaty.

2. Fire clay, dark gray.

I. Sandstone, thinly bedded, somewhat shaly, (exposed to water

Figure 1.39 Bluff on Coal Creek at Richardson stine.

Three miles southeast of Ferry $P$. $O$. 